\title{
THE TANGLED SEINE: A SURVEY OF MARITIME PERSONAL INJURY REMEDIES
}

LAw and Equity are now one; Admiralty remains apart. Perhaps it is not yet time to question the necessity of this historic disjunction, ${ }^{1}$ but it may be recognized that a certain amount of friction will be generated through the parallel operation of separate admiralty and law systems, each with its characteristic remedies, rights and procedures. ${ }^{2}$ In the field of maritime personal injury cases, however, the inherent difficulties of a dual system have been severely aggravated by the operation of a series of additional factors which serve partially to explain, if not to justify, the present complexity that besets an essentially simple legal problem. ${ }^{3}$

It cannot be said that the respective cognizances of King's Bench and the Admiralty courts in England were ever clarified beyond dispute. In the United States, the Constitution engrafted upon this ill-defined judicial dual-

1. There is no current articulate movement favoring a merger of Law and Admiralty. The need for flexibility in the operation of the present dual system receives occasional oblique reference. See McDonald v. Cape Cod Trawling Co., 71 F. Supp. S8S (D. Mass. 1947); Richardson \& Sons v. Conners Marine Co., 141 F. $2 d 226$ (C.C.A. 2d 1944); Morricon, The Remedial Powers of the Admiralty, 43 YALE L. J. 1 (1933).

2. "The statutes, the Rules of Civil Procedure, and the decisions of the courts all clearly recognize that jurisdiction in admiralty is quite separate and apart from jurisdiction at law. Admiralty is still a separate field of law and has its own rules, methods, and procedure." Rowley v. Sierra S. S. Co., 48 F. Supp. 193, 195 (N. D. Ohio 1942). And see Panama R. R. Co.v. Johnson, 264 U. S. 375, 388-9 (1924).

3. Standard general statements of the law of maritime personal injuries include: Axtell, Merchant Searren's Law (1943) (a simplified survey for the layman); 1 BeneDICT, ADMIRALTY $\S \S 22,25,27-31,134,140-83$ (6th ed. 1940); 4 id. $\S \S 627-42$; RoBINSoN, ADMrRalty \$\$ 10, 13-8, 35-14, 57 (1939); Robinson, The Seaman in American sfarilime Law, 16 B.U.L. REv. 283 (1936); Willock, Commentary on Afaritime Workers, 46 U.S.C.A. 211 (1944), as revised, 46 U.S.C.A. 12 (Supp. 1946). See also LoRd aNd Spracue, CaSEs ox ADMIRALTY, c. $1, \S \S 4,9,10$ (2d ed. 1939); id., c. 3. Radical developments in the field under discussion have rendered these studies inaccurate in significant respects. See 32 VA. L. REv. 1177 (1946).

4. Historical reviews of the jurisdictional struggle between the English Admiralty Courts and the Common Law Courts may be found in 4 BExedict, op. cil. supra note 3, \$\$ 672-704; RosCOE, AdMIRALTY PRACTICE 1-36 (5th ed. 1931); Laing, Hisloric Origirs of Admiralty Jurisdiction in England, 45 Mirce. L. REv. 163 (1946); Mfears, The History of the Admiralty Jurisdiction in 2 SeLECT Essays IN ANGLO-Axericax LEgal History 312 (1908); Morris, The Jurisdiction and Practice of the Hight Court of Admirally of England, 4 SoL. J. 115,137 (1859). See also the opinion of Story, J., in DeLovio v. Boit, 7 Fed. Cas. 418, No. 3, 776 (C.C.D. Mass. 1815).

Additional complications arise from the fact that the admiralty courts of the colonies developed quite disparate concepts of remedies and jurisdiction from those adopted in England. The Supreme Court in Hendry Co. v. Moore, 318 U. S. 133 (1943), had occasion to review the powers of the colonial courts of admiralty in detail. The footnotes to the majority opinion of Stone, C. J., contain an elaborate collection of the relevant historical authorities. Black, J., dissenting, retaliates with further citation. For a brief summary of this point consult 4 BENEDICT, op. cit. supra note 3 , $\$ \S 707-18$. 
ity a political duality of sovereignty gearing the jurisdiction of the admiralty courts to the federal political unit ${ }^{5}$ and thus compounded the problems of adjustment of jurisdiction and applicable substantive principles by the injection of serious constitutional issues. The constitutional grant was not exclusive, however, and the drafters of the Judiciary Act of 1789 , jealous of their states' newly won sovereignty, incorporated in the statutory provision for federal maritime jurisdiction a clause "saving to suitors the right of a common law remedy where the common law is competent to give it," o interpreted as granting the suitor his election of state or federal forum except where the action is the ancient and peculiarly maritime proceeding in rem. The in rem action was not a "common law remedy" and only the federal courts were held competent to provide it." Over a period of a century the Supreme Court proceeded to develop the national admiralty law jettisoning one traditional English doctrine after another, ${ }^{8}$ while the state courts applied their own doctrines and their own procedures in maritime cases brought in the state forum by virtue of the "saving to suitors" clause. Suddenly Mr.

5. U. S. Consr. Art. III, $\S 2$ : "The judicial power shall extend . . . to all Cases of admiralty and maritime Jurisdiction. . . ." Perhaps because the point is self-evident it is seldom noted that it is this constitutional gearing of admiralty jurisdiction to federal power which introduces into the subject its major complexities. Attempts to tinker with admiralty jurisdiction invariably run afoul of problems of federal and state sovereignty. The involved remedial structure surrounding maritime personal injuries is to a considerable extent attributable to this factor.

6. 1 STAT. $76-7$ (1789), 28 U.S.C. $\$ \$ 41(3), 371$ (1940). Note that the asserted necessity of this qualification lies in the constitutional provision which links admiralty jurisdiction with the federal judiciary.

7. DeLovio v. Boit, 7 Fed. Cas. 418 , No. 3,776 (C.C.D. Mass. 1815); Waring v. Clarke, 5 How. 441 (U. S. 1847); The Moses Taylor, 4 Wall. 411 (U. S. 1866); The Hine v. Trevor, 4 Wall. 555 (U.S. 1866); The Belfast, 7 Wall. 624 (U.S. 1868); The Glide, 167 U.S. 606 (1897); The Robert W. Parsons, 191 U.S. 17 (1903); Rounds v. Cloverport Foundry and Machine Co., 237 U.S. 303 (1915) (distinguishing an in personam action with a concurrent attachment).

It is the general statement in all treatises that the state courts may entertain no in rem suit against a res cognizable in admiralty. 1 BENEDICT, op. cil. sulpra note 3, at 21; RourNson, ADArRalty 359 (1939). This has today been modified sharply, however, by the decision in Hendry Co. v. Moore, 318 U.S. 133 (1943), wherein the power of the state to declare forfeit a maritime res in illegal use was upheld.

8. For the history of this development, consult 4 BENEDICT, op. cit. supra note 3 , $\$ 734$ et seq.; Sprague, The Extension of Admiralty Jurisdiction and the Growth of Substantive Marilinte Law in the United States Since 1835 in 3 Law, A CENTURY of Progress 294 (1937); Hughes, Jurisdictional Conflicts Between Admiralty and Common Law Coutrts, 6 TEX. B. J. 156 (1943).

9. Cases reflecting this older practice include: La Bourgogne, 210 U.S. 95 (1908); The Hamilton, 207 U.S. 398 (1907); Knapp, Stout \& Co. v. McCaffrey, 177 U. S. 638 (1900); The J. E. Rumbell, 148 U.S. 1 (1893); The Lottawanna, 21 Wall. 558 (U.S. 1874) (the harbinger of the Jensen case, establishing the rule of "uniformity" within the federal judiciary); Atlee v. Packet Co., 21 Wall. 389 (U.S. 1874); Steamboat Ca. v. Chase, 16 Wall. 522 (U.S. 1872); Ex parte McNiel, 13 Wall. 236 (U.S. 1871); Cooley v. Bd. of Wardens, 12 How. 298 (U.S. 1851); New Jersey Steam Navigation Co. v. Merchants Bank of Boston, 6 How. 344 (U.S. 1848). 
Justice McReynolds, speaking for a bare majority of the Court in the celebrated Jensen case, announced in 1917 that the intention of the forefathers in granting maritime jurisdiction to the federal judiciary was to guarantee "uniformity" in the law of the sea, and that this "uniformity" must be retained regardless of the forum of litigation. ${ }^{10}$ The case represents the Erie $v$. Tompkins of the admiralty field except that the shoe is on the other foot, the state courts being obliged to follow "substantive" law" as declared by the Supreme Court, but left free to apply their own "procedure." 11 Qualified by

10. So. Pacific Co. v. Jensen, 244 U.S. 205 (1917). A workman lislled in New York harbor had applied for and received compensation under that state's worl:men's compansation statute. The Supreme Court held the award invalid and asserted the proposition that a state has no power to legislate concerning matters maritime where the legislation would work "material prejudice to the characteristic features of the general maritime law." The decision is also predicated upon a second ground that only a "common law remedy" is saved to the suitor, and that in no sense may workmen's compensation be considered a "common law remedy." It had already been held, however, that state modifications in the common law remedy did not foreclose a suit under the "saving to suitors" clause. Steamboat Co. v. Chase, 16 Wall. 522 (U.S.1872); Berton v. Tietjen \& Lang Dry Dock Co., 219 Fed. 763 (D.N.J. 1915); and see the dissents of Holmes and Pitney, JJ., in the Jersers cace.

11. The full implications of the doctrine remain yet unclarified, but the decisions in the Jensern case and Chelentis v. Luckenbach S.S. Co., 247 U.S. 372 (1918), distinguighing between "rights" and "remedies," would seem to permit of no other conclusion. Sce Carlisle Packing Co. v. Sandanger, 259 U.S. 255 (1922); Knapp v. United States Trans. Co., 181 App. Div. 432, 170 N.Y.Supp. 384 (4th Dep't 1918). The usual difficulties in discriminating "substance" from "procedure" are encountered. In Belden v. Chase, 150 U.S. 674 (1893), it was decided that the common law rule of contributory negligence as a bar should apply in admiralty actions brought by virtue of the "saving to suitors" clause, to the exclusion of the maritime rule of divided damages. The decision remains on the books and is followed, though it would seem irreconcilable with the many cases following the Chelentis doctrine. Precedents are collected in 1 BENEDICT, op. cit. supra note 3 , at $55 \mathrm{n}$. 77. See also Willsins v. Foss Launch \& Tug Co., 20 Wash. 2d 422, 147 P. 2d 524 (1944), refusing to depart from the old rule in the absence of a later express mandate of the highest court. The decision seems influenced by the opinion of Hand, J., in In re Pennsylvania R. Co., 48 F. 2d 559 (C.C.A. 2d 1931) where the contributory negligence rule is categorized as a matter of "procedure." Consult Sprague, Disided Damages, 6 N.Y.U.L.Q.REv. 15 (1928); Mlole and Wilson, A Study of Comparative Negligence, 17 CORs. L. Q. 333 (1932); 34 CALIF. L. REv. 599 (1946).

In the very recent admiralty case of Lascovich v. Samovar, 1947 Am. Mar. Cas. 1046 (N.D.Cal. 1947), the district court adopts and applies the local state rule of manufacturer liability to parties not buyers where failure to discover a defect led to the injury. Though this rule is not adopted in all states, nor presumably will be applied by federal courts in jurisdictions where the doctrine is not followed, the essential "uniformity" of maritime law" will not be "prejudiced", the court explains.

The Supreme Court has recently decided that the state courts must give effect to the admiralty doctrine that the burden of proof falls to the party seeling to establish the validity of a seaman's release, even though the state's law places the burden upon the party urging its invalidity. Garrett v. Moore-McCormack Co., 317 U. S. 239 (1942), 17 TEsP. L.Q. 194 (1943), 91 U. of P. L. REv. 667 (1943). A similar result has been reached regarding classification of burden of proof as substantive under the Eric r. Tomplins doctrine. $C f$. Sampson v. Channel, 110 F. 2d 754 (C.C.A. 1st 1940), cert. denied, 310 U.S. 650 (1940).

There is no indication that the decision in Erie Ry. Co. v. Tomplins, 30t U.S. 64 
the added shadowy concept that state law may operate where the matter is "maritime but local," 12 and where it will work no prejudice to the "essential uniformity" of the admiralty law, the Jensen doctrine is a vague common denominator that underlies the whole field of modern admiralty law. ${ }^{13}$ Against this perplexed doctrinal background were thrust a series of federal statutes ${ }^{14}$ radically modifying the traditional rights of injured maritime workers, and raising large new remedial and jurisdictional questions for judicial determination. The increasingly rapid and observable impact of twentieth century social philosophy and a "new" Supreme Court has provided a final unsettling influence upon an already uncertain segment of the law.

(1938), will affect the uniformity rule of the Jensen case. Apparent conflict may be rationalized on the basis of the recognized pre-existence of a federal maritime law, and the constitutional grant.

12. This limiting doctrine arose almost immediately upon the announcement of the Jensen rule, and indeed was implicit in that opinion itself. See 244 U.S. 205, 216 (1917). Western Fuel Co. v. Garcia, 257 U.S. 233 (1921); Grant Smith-Porter Ship Co. v. Rohde, 257 U.S. 469 (1922). Consult Robinson, Admiralty $\$ 14$ (1939). See pp. 269-70 infra.

See 1 BENEDICT, op. cit. supra note 3, $\$ \S 34-5$, for collection and treatment of the cases "delineating" the scope of permissible applicability of state legislation in matters maritime.

13. The Jensen case represents a favorite topic for scholastic disputation. Conlen, Admiralty's Jurisdictional Problem (Twenty-Five Years After the Jensen Case), 16 Temp. L.Q. 311 (1942); Conlen, Ten Years of the Jensen Case, 76 U. oF PA. L. REv. 926 (1928); Cunningham, The Tables Turned-Lord Coke Demolished, 55 As. L. Rev. 685 (1921); Cunningham, Is Every County Court in the United States a Court of Admiralty? 53 AM. L. REv, 749 (1919); Dodd, The New Doctrine of the Supremacy of Admiralty Over the Common Law, 21 CoL. L. Rev. 647 (1921); Fell, Recent Problems in Admirally Jurisdiction, 40 Jouns Horkins UnIVERSITX STUdies 287 (1922); Hough, Admirally Jutrisdiction- of Lata Years, 37 HARv. L. REv. 529 (1924); Hughes, Jurisdictional Conflicts Between Admiralty and Common Law Coutts, 6 TEx. B. J. 156 (1943); Morrison, Workmen's Compensation and the Maritime Lan, 38 YALE L.J. 472 (1929); Palfrey, The Common-Law Courts and the Law of the Sea, $36 \mathrm{HARV}$. L. REv. 777 (1923); Stumberg, Marilime Cases in Common Law Courts, 3 TEx. L. REv. 246 (1925); Wright, Uniformity in the Maritime Law of the United States, 73 U. OF PA. L. REv. 123, 223 (1925); Note, Workmen's Compensation for Maritime Employces: The Jensen Doctrine Re-examined, 10 U. of CEI. L. Rev. 339 (1943); Note, A Memorandum Decision, 40 HARV. L. Rev. 485 (1927).

The view of the present Supreme Court is somewhat more humble than the dogmatic interpretation of Mr. Justice McReynolds. "Examination of the legislative history of the Judiciary Act of 1789 does not disclose precisely what its framers had in mind when in $\$ 9$ they used the phrase 'common law remedy'." Stone, C. J., in Hendry Co. v. Moore, 318 U.S. 133, 148 (1943). The late Chief Justice's disapproval of the entire Jentsen doctrino is reflected in his dissent to Davis v. Dep't of Labor, 317 U. S. 249 (1942). See, too, Mr. Justice Frankfurter for the Court in Caldarola v. Thor Eckert Co., 67 Sup. Ct. 1569 (1947), where he concedes that the "rights" and "remedies" dichotomy and the state and federal duality concept are not entirely clear. $C f$. Rutledge, J., dissenting, $i d$. at 1572.

14. Of direct relevance to the subject of this discussion are $41 \mathrm{STAT} .1007$ (1920), 46 U.S.C. § 688 (1940) (Jones Act); 44 STAT. 1424 (1927), 33 U.S.C. § 901 et seg. (1940) (Longshoremen's and Harbor Workers' Compensation Act); 41 STAT. 537 (1920), 46 U.S.C. $\$ 761$ et seq. (1940) (Death on the High Seas Act). See generally for statutes pertaining to rights of seamen, 46 U.S.C., c. 18 (1940); AXTELL, op. cit. supra note 3; Robinson, The Seaman in American Admirally Law, 16 B.U.L. REv. 283 (1936). 
The sheer multiplicity of remedy and forum available under slightly varying circumstances to the maritime worker who is injured is completely incommensurate with the difficulty of the tort problem presented, and a considerable portion of the uncertainty which is present derives from this very multiplicity. Rights and selection of the proper remedy are made to turn upon a series of more or less predictable, more or less irrational distinctions of fact or law. For purposes of discussion, it is convenient to classify these rights and remedies into those which were available to the injured seaman under the general maritime law, and those which were later superimposed by statute.

\section{Remiedies Under General Maritume Law}

\section{Maintenance and Cure}

In the remedy of maintenance and cure, the general law of the sea developed the first operating system of workmen's compensation known to AngloSaxon law. Proudly the admiralty courts trace the ancestry of the injured seaman's right to maintenance and cure back some twenty-five hundred years to the legendary law of the thalassocracy of Rhodes. ${ }^{15}$ Under the doctrine as interpreted by American admiralty law, ${ }^{16}$ any seaman who is injured or taken ill while in the service of his ship is entitled absolutely to compensation for his expenses of maintenance and cure "at least to end of the voyage", ${ }^{17}$ and under modern interpretation for a "reasonable" time thereafter. ${ }^{18}$

15. AxreLL, op. cit. supra note 3 , at 53. Whether the seamen who sailed under the Colossus were entitled to such compensation is not actually known, but it is certain that the great admiralty codes drawn up in the era of the Crusades to regulate the merchant trade of the cities of the Hanse League and of Oleron and Wisbuy made provision for the linbility of the ship owner to recompense any seaman injured while in the service of his ship. Laws of Oleron, Arts. VI, VII; Laws of Wisbuy, Arts. XVIII, XIX; Laws of the Hanse Towns, Arts. XXXIX, XLV; Marine Ordinances of Louis XIV, Marine Contracts, Title Fourth, Arts. XI, XII. The codes are reprinted in 30 Fed. Cas. 1171-1216. See Rosniso:, ADsurnlty $\S 36(1939)$.

16. The classic expositions in American case law are the opinions of Story, J., in Harden v. Gordon, 11 Fed. Cas. 480, No. 6047 (C.C.D. Me. 1823), and Reed v. Canfield, 20 Fed. Cas. 426, No. 11,611 (C.C.D. Miass. 1832); The Osceola, 189 U.S. 158 (1903). Too recent to be considered classic, Aguilar v. Standard Oil Co. of N. J. and its companion case, Waterman S.S. Corp. v. Jones, 318 U.S. 724 (1943), contain thorough treatments of the subject. Consult 1 BENEdict, op. cit. supra note 3, at 61, 253, 364; LORD aNd SpraGUE, CASES ON Admiralty 331 et seq. (1939); Robinson, Adurralty §36 (1939); Comment, Admirally Right to Afaintenance and Cure, 38 ILL. L. REv. 193 (1943) (a complete and excellent analysis).

17. This vague phrase is from The Osceola, 189 U.S. 158 (1903). It is probable that the right to wages extends to but not beyond the termination of the voyage. City of Alevandria, 17 Fed. 390 (S.D.N.Y. 1883); William Penn, 1925 Am. Mar. Cas. 1316 (E.D.N.Y. 1925); Calmar S.S. Corp. v. Taylor, 303 U.S. 525 (1938); MICManus v. Marine Transport Lines, 149 F. 2d 969 (C.C.A. 2d 1945) (where the cases are collected and reviewed). But of. The Bouker No. 2, 241 Fed. 831 (C.C.A. 2d 1917); Meyer v. Dollar Line S.S. Co., 49 F. 2d 1002 (C.C.A.9th 1931).

18. The Pochasset, 295 Fed. 6 (C.C.A. 1st 1924); The Bouker No. 2, 241 Fed. 831 
The right is said to arise in neither tort nor contract, but to be an incident of the seaman's status ${ }^{19}$ enforceable against the owner or operator or against the vessel "down to the last plank." Since it is treated as a "relational" right, the recovery of maintenance and cure does not bar prosecution of any other contractual or delictual remedies which may be available to the seaman for his injury or illness. ${ }^{20}$ Negligence on the seaman's part has no rele-

(C.C.A. 2d 1917); The Ipswich, 46 F. 2d 136 (D.Md. 1930); The Eastern Dawn, 25 F. $2 \mathrm{~d} 322$ (E.D.Pa. 1928); Geistlinger v. International Mercantile Marine Co., 295 Fed. 176 (S.D.N.Y. 1924); The Cliftwood, 280 Fed. 726 (S.D.Ala. 1922); The W. L. White, 25 Fed. 503 (S.D. N.Y. 1885). Contra: The Tammerlane, 47 Fed. 822 (N.D.Cal. 1891); The J. F. Card, 43 Fed. 92 (E.D.Mich. 1890); The City of Alexandria, 17 Fed. 390 (S.D.N.Y. 1883). These latter cases refused to follow the liberal doctrine as expounded by Judge Story in Reed v. Canfield, 20 Fed. Cas. 426, No. 11,641 (C.C.D.Mass. 1832). For a bizarre bit of reasoning rationalizing the conflicting cases, see Enochasson v. Freeport Sulphur Co., 7 F. 2d 674 (S.D. Tex. 1925); 1 BENEDICT, op. cit. supra note 3, at 254 .

The courts have been especially troubled by the problem of duration of liability where the seaman suffers from an incurable disease. The shipowner is clearly not obligated to make payments until death, the general rule seeming to require only that the reward be paid until medical art has cured to the extent that it is possible to cure. RoniNson, ADMIRALTy 295-9 (1939); Luksich v. Misetich, 140 F. 2d 812 (C.C.A. 9th 1944). See Lindquist v. Dilkes, 127 F. 2d 21 (C.C.A. 3d 1942) (urinary trouble); Interocean S. S. Co. v. Behrendsen, 128 F. 2d 506 (C.C.A. 6th 1942) (intestinal trouble); Loverich v. Warner Co., 118 F. 2d 690 (C.C.A. 3d 1941) (cancer); Calmar S. S. Co. v. Taylor, 92 F. 2d 84 (C.C.A. 3d 1937), $r e v ' d, 303$ U.S. 525 (1938) (Buerger's Disease). Intervening employment does not appear to affect the right to recovery. Loverich v. Warner Co., supra; Note, 22 OH1o Ops. 256 (1942).

19. Robinson, AdMIralty 293 (1939); Waterman S. S. Co. v. Jones, 318 U.S. 724, 730 (1943); Cortes v. Baltimore Insular Line, Inc., 287 U.S. 367, 371 (1932); The Osceola, 189 U.S. 158, 172 (1903). The significance of this special characterization of the right as an "incident to status" may be observed in the very recent case of Taylor v. United Fruit Co., 1947 Am. Mar. Cas. 164 (N.Y. City Ct. 1946) (standby seaman not under articles collects maintenance and cure), and Martinez v. Marine Transport Lines, 1947 Am. Mar. Cas, 529 (N.Y. City Ct. 1947) (seaman collects maintenance and cure where injured before signing articles). Where the result of the decision does not require that the duty be termed "rclational", the courts will loosely use the "contract" syntax. See, e.g., Dryden v. Ocean Acc. and Guar: Corp., 138 F. 2d 291 (C.C.A. 7th 1943).

20. 4 BENEpICT, op. cit: supra note 3, at 199; Pacific Steamiship Co. v. Peterson, 278 U.S. 130,138 (1928). More recent affirmations include Muise v. Abbott, 160 F. $2 d 590$ (C.C.A. Ist 1947); Runyan v. Great Lakes D. \& D. Co., 141 F.'2d 396 (C.C.A. 6th 1944); Rankin v. Iron City S. \& G. Corp., 71 F. Supp. 26 (W.D.Pa. 1947); Mosseller v. United States, 1947 Am. Mar. Cas. 913 (S.D.N.Y. 1947). See also Jones v. Waterman S. S. Co., 155 F. 2d 992 (C.C.A. 3d 1946), reversing the District Court decision that the seaman could not urge both the Jones Act and maintenance and cure as separate grounds of recovery. Smith v. Lykes Bros.-Ripley S. S. Co., 105 F. 2d 604 (C.C.A. 5th 1939), and Chiloil, 1939 Am. Mar. Cas: 1023 (S.D.N.Y. 1939), seem to require that separate actions be brought. Conlra: The Progress, 21 F. Supp. 572 (W.D.Wash. 1937); Owens v. Hammond Lbr. Co., 8 F. Supp. 392 (N.D.Cal. 1934); Roebling's Sons Co. v. Erickson, 261 Fed. 986 (C.C.A. 2d 1919). And see Gibson v. International Freighting Corp., 71 F. Supp. 875 (E.D.Pa. 1947), where plaintiff was refused his motion to withdraw his claim for maintenance and cure after having joined it with another cause. Muise v. Abbott, supra, emphasizes the distinctive nature of the cause of action for maintenance and cure in permitting recovery against the shipowner even though the seaman injured on a dock had given a release to the wharf-owner after a settlement. 
vance to the collection of maintenance and cure in general, ${ }^{21}$ although recovery has occasionally been denied where the seaman was guilty of gross negligence or wilful misconduct, ${ }^{22}$ or had wilfully concealed a latent illness or injury. ${ }^{23}$

It is probable that the old cases on maintenance and cure would have permitted recovery by the signed crew member who had suffered injury while off duty ashore; ${ }^{24}$ but, influenced perhaps by the "arising out of" requirement of statutory workmen's compensation schemes, there slowly accumulated a body of authority which denied recovery except where the injury occurred "in the line of duty" on shipboard. ${ }^{25}$ "This doctrine was expressly branded heresy by the Supreme Court in the recent appositely titled case of Waterman S.S. Co. v. David Jones. ${ }^{.0}$ Reviewing the older cases, and utilizing the usual argument that the peculiar hazards of the mariner's calling require that he be granted special protection, the Court pointed out that shore leave constitutes necessary rehabilitation to the seaman, enabling him to perform his duties while on ship board, that it militates to the benefit of

21. "Conceptions of contributory negligence, the fellow-servant doctrine, and assumption of risk have no place in the liability or defense against it." Aguilar v. Standard Oil, 318 U.S. 724, 731 (1943).

22. Peterson v. The Chandos, 4 Fed. 645 (D.Ore. 1880); The Ben Flint, 3 Fed. Cas. 183, No. 1,299 (D. Wisc. 1867). Venereal disease and accidents arising from excessive imbibition seem least in favor. The authorities are collected in Aguilar v. Standard Oil, stpra note 21, at $731, \mathrm{n} .10,11$

23. Tawada v. United States, 1947 Am.Mar.Cas. 947 (C.C.A. 9th 1947); Burns v. United States, 62 F. Supp. 603 (E.D.Pa. 1945); Writer v. The Richmond, 30 Fed. Cas. 718, No. 18,104 (D.Pa. 1807).

24. There is no question that this was Mr. Justice Story's opinion, and the dicta in Reed v. Canfield, 20 Fed. Cas. 426, No. 11,641 (C.C.D.Mlass. 1832), clearly indicates this view of admiralty history. See also The S. S. Berwindglen, 88 F. $2 d 125$ (C.C.A. 1st 1037).

25. These cases and the bootstrap method by which each raised itself upon the others are traced in 38 ILL. L. Rev. 193, 201-7 (1943). Meyer v. Dollar S. S. Line, 49 F. 2d 1002 (C.C.A. 9th 1931); Collins v. Dollar S. S. Lines, 23 F. Supp. 395 (S.D.N.Y. 1938); The President Coolidge, 23 F. Supp. 575 (N.D.Wash. 1938); Smith v. American South African Line, Inc., 37 F. Supp. 262 (S.D.N.Y. 1941); Wahlgren v. Standard Oil Co. of N. J., 42 F. Supp. 992 (S.D.N.Y. 1941). One case only had squarely taken the contrary view. The J. M. Danziger, 1938 Am.Mar.Cas. 685 (S.D.N.Y. 1937).

Two distinct issues are involved in these cases, but the decisions do not always discriminate between them. (1) May the recovery be had for injuries suffered ashore? (2) May the recovery be had for injuries not sustained in the "line of duty"? The latter was considered the primary consideration apparently, for the injured seamen in a fer cacss had succeeded when injured performing a chore on land. The Montezuma, 19 F. $2 \mathrm{~d} 355$ (C.C.A. 2d 1927). But a seaman injured on board in a "friendly scuffe" was denicd recovery since he was not in the service of his ship, the court drawing analogy to the United States Navy notion of "line of duty." Meyer v. Dollar S.S. Line, sapra. See Note, 4 L.R.A. (n.s.) 71 (1906) for older cases as to the seaman's right to maintenance and cure if injured in personal avocation.

26. The opinion of the court was delivered for the Watcrman case and a companion case. Aguilar v. Standard Oil Co. of N. J., 318 U.S. 724 (1943); 22 TEx. L. KEv. 239 (1944); 7 U. of Detrort L.J. 18 (1943). For a note on the circuit court opinion, 130 F. 2d 797 (C.C.A. 3d 1942), see 29 VA. L. REv. 498 (1943). 
the ship, and that hence the owner's and the vessel's liability to pay maintenance and cure extends to compensate all injuries sustained by the seaman so long as he is signed on the vessel, regardless of the situs of the injury. ${ }^{27}$ The case represents an affirmative assertion of the distinctly favorable attitude of the present majority toward the extension of absolute liability as a technique for placing the burdens of workmen's personal injuries upon the society as a whole. Presented with two equally respectable bodies of precedent, the Court unhesitatingly chose that one which supported such an extension.

With the Waterman decision, the substantive elements of the seaman's right to maintenance and cure may be considered relatively well clarified, though litigation continues on the questions of who is a "seaman" ${ }^{28}$ for purposes of its remedy, and what shall be considered a "reasonable" time of payment. It is also settled that the mariner may enforce his right by a libel either in personam or in rem in the federal courts on the admiralty side, and that, by virtue of the "saving to suitors" clause, an in personam action may be brought in the state courts and on the common law side of the courts of the United States. ${ }^{29}$ But there is confusion as to the jurisdictional requirements for such a common law action in the federal court. The proposition

27. Thus the Waterman decision presents a clear affirmative to both of the questions suggested in note 25 supra. The pragmatic effect of the opinion would seem to be a complete abandonment of the "service of the ship" requirement, but the opinion restricts itself to the geographical facts in the case and says "How far [liability] extends beyond that point we need not now determine." 318 U.S. 724, 737 (1943). Interesting cases extending the doctrine still further include Nowery v. Smith, 69 F. Supp. 755 (E.D.Pa. 1946), aff'd, 161 F. 2d 732 (C.C.A. 3d 1947) (seaman injured in barroom fracas); Moss v. Alaska Packers Ass'n, 1945 Am. Mar. Cas. 493 (App. Dept. of Sup. Ct., San Francisco, Cal. 1945) (another barroom case); Sullivan v. United States, 1947 Am. Mar. Cas. 426 (S.D.N.Y. 1947) (scaman assaulted in street); Taylor v. United Fruit Co., 1947 Am. Mar. Cas, 164 (N.Y.City Ct. 1946) (standby seaman assaulted). One opinion delivered soon after the Walerman decision attempts to restrict that holding closely to its facts. The court seems to apply the strange criteria that the injury must be received in the vicinity of the ship and upon private, not public, property. Siclana v. United States, 56 F. Supp. 442 (S.D.N.Y. 1944). A court has recently balked at holding the shipowner liable where the seaman turned an ankle while visiting a friend's house seven miles from his own home where he was temporarily on leave, but the rationale is obscure. Smith v. United States, 1947 Am. Mar. Cas. 481 (E.D.Va. 1946).

28. Cases are collected in 38 ILL. L. REv. 193, at 194 n. 6 (1943). The decisions are not predictable; it is agreed that the facts of each case govern and that the result must depend upon the purpose for which the injured person is to be classified. See Roninson, AdMIRALTY $\S 35$ (1939); Anderson v. Manhattan Ltge. Co., 148 F. 2d 971 (C.C.A.2d 1945). It is of significance to note, however, that longshoremen are uniformly agreed not to be "seamen" for purposes of maintenance and cure. Calvino v. Farley, 23 F. Supp. 654 (S.D.N.Y. 1938); C. Flanagan \& Sons Inc. v. Carken, 11 S.W.2d 392 (Tex. Civ. App. 1928), 42 Harv. L. REv. 820 (1929). See Sieracki v. Seas Shipping Co., 149 F.2d 98, 101 (C.C.A.3d 1945); Yaconi v. Brady and Gioe, Inc., 246 N.Y. 300, 307, 158 N.E. 876, 878 (1927).

29. 4 Benedict, op. cit. supra note 3, at 200; Robinson, AdMiralty 292 (1939); The Bouker No. 2, 241 Fed. 831 (C.C.A.2d 1917). See cases collected in McDonald v. Cape Cod Trawling Co., 71 F. Supp. 888, 891 (D.Mass. 1947). 
is asserted in Benedict's treatise that both the $\$ 3,000$ jurisdictional amount and diversity of citizenship are necessary for the action to be entertained, ${ }^{20}$ but he cites no authority, and subsequent cases supporting the view mainly cite Benedict. ${ }^{31}$ There is some support for the view that the doctrine of pendency will give the federal court jurisdiction over the claim for maintenance and cure where it is joined with a related cause of action for which jurisdiction is regularly established. ${ }^{32}$

The essential substantive and administrative simplicity of the doctrine of maintenance and cure renders it the least controversial of the remedies accorded injured seamen. It would seem that the limits of its possible applicability have been reached and that no radical developments may be anticipated. But the benefits which may be recovered are at best inadequate for they are in no way geared to wages but are closely restricted to small periodic payments to recompense for expenses incurred while the worker is incapacitated. ${ }^{33}$ Once virtually the sole remedy of the injured seaman, maintenance and cure has come to represent a supplemental guaranteed remedy, helpful, but no longer primary.

\section{Maritime Tort: Unseaworthiness}

The general maritime law perhaps afforded one exception to the proposition that maintenance and cure represented the exclusive remedy available

30. 4 BENEDICT, op. cit. supra note 3 , at 201.

31. Modin v. Matson Nav. Co., 128 F. 2d 194 (C.C.A.9th 1942); Hiltz v. Atlantic Refining Co., 57 F. Supp. 308 (E.D.Pa. 1944). But see Thornes v. Socony Vacuum Oil Co., 37 F. Supp. 616 (S.D.N.Y. 1940). The view taken by Benedict would seem the proper one if the premise be adopted that the federal court is today a bivalve and that jurisdictional competence of one chamber does not imply similar authority by the other. See discussion in note 109 infra. It is strange, however, that the question should remain unsettled and that there should be so little actual authority for any position.

32. Lindquist v. Dilkes, 127 F.2d 21 (C.C.A.3d 1942); Nolan v. General Seafoods Corp., 112 F.2d 515 (C.C.A. 1st 1940); Stevens v. R. O'Brien \& Co., 62 F.2d 632 (C.C.A. 1st 1933). See particularly the extended discussion by Wyzanski, J., in MIeDonald v. Cape Cod Trawling Corp., 71 F. Supp. 888 (D.Mass. 1947).

33. A judgment obtained does not bar later actions if it appears that further expenses have been incurred. Calmar S.S. Corp. v. Taylor, 303 U.S. 525 (1938). Generally lump sum payments based on expectancy are frowned upon. Loverich v. Warner Co., 118 F.2d 690 (C.C.A.3d 1941). Since the payments are restricted to actual expenses, the seaman was held entitled to no maintenance where he was living with his parents. United States v. Johnson, 160 F.2d 789 (C.C.A.9th 1947). Furthermore, the employer's duty is discharged when he presents a certificate of entry into a United States Marine Hospital, at least for the period while the seaman is an in-patient. Robinson, AdunRalty 295 (1939); United States v. Loyola, 161 F.2d 126 (C.C.A.9th 1947); Tawada v. United States, 1947 Am. Miar. Cas. 947 (C.C.A.9th 1947); Moyle v. National Petroleum Tr. Co., 150 F.2d 840 (C.C.A.2d 1945) (discharge from hospital at request of seaman does not bar him from further suit for maintenance and cure). Convention No. 55 of the International Labor Conference, concerning the shipowner's obligation to seamen, was ratified by the Senate in 1938. Implementing legislation passed the House of Representatives in 1939. 84 CoNG. Rec. 10546 (1939); H.R. 6881, 76th 
to the injured seaman. ${ }^{34}$ Derived, it is said, from the ancient right of the crew to abandon an unseaworthy vessel, ${ }^{35}$ the doctrine in admiralty developed that a shipowner was under a non-delegable ${ }^{36}$ duty to indemnify any seaman injured as a result $t^{37}$ of the unseaworthiness of the vessel. ${ }^{33}$ The admiralty judge of a few centuries back would probably not be clisturbed at the modern interpretation of the remedy of maintenance and cure, but he might well be excused for raising an eyebrow upon learning of the vicissitudes of the remedy for "unseaworthiness."

There are cases on record which hold or imply that the negligence of the shipowner is a necessary factor in his liability under the doctrine of "unseaworthiness." ${ }^{39}$ Their interest today is primarily historical. Step by step, the highest tribunal has rendered the nature of the shipowner's duty more exacting, his obligations more extensive, and his defenses less effective. ${ }^{40}$ In 1939, assumption of risk was banned as a plea to an action grounded upon defective equipment; ${ }^{41}$ and in 1943 the owner was held liable under the

Congress, 1st Session. The Convention works no major changes in respect to maintenanca and cure. See 4 BENEDICT, op. cit. supra note 3 , at 293 et seq.

34. Mention must be made of a derivative right which inured to the seaman and which may be treated as another exception. In the event of failure on the part of the ship to pro. vide adequate maintenance and care to its injured seamen, there was created a right of action to indemnity for aggravation caused by the neglect to treat. Of significance when there was no general cause of action against the shipowner for negligence, this collateral, almost penal, sanction has been absorbed by the Jones Act, p. 258 infra. Consult Robinson, The Seaman in American Admiralty Law, 16 B.U.L. Rev. 283, 294 (1936); The Iroqutois, 194 U.S. 240 (1904); The Cuzco, 154 Fed. 177 (C.C.A.2d 1907); Cortes v. Baltimore Insular Line, 287 U.S. 367 (1932), and cases reviewed therein.

35. The Arizona v. Anelich, 298 U.S. 110, 121n.2 (1936); Mahnich v. Southern S.S. Co., 321 U.S. 96, 99 (1944). The accuracy of this reference is problematical. Sec Seas Shipping Co. v. Sieracki, 328 U.S. 85, 91n.7 (1946).

36. Shields v. United States, 1947 Am. Mar. Cas. 453 (E.D.Pa. 1947); Francis v. Seas Shipping Co., 158 F.2d 584 (C.C.A.2d 1946); Sabine Towing Co. v. Brennan, 72 F.2d 490 (C.C.A.5th 1934); Christopher v. Grueby, 40 F.2d 8 (C.C.A.1st 1930).

37. The injury must have been caused by the unseaworthy condition. The Baymead, 88 F.2d 144 (C.C.A.9th 1937); Pittsburgh S.S. Co. v. Palo, 64 F.2d 198 (C.C.A. 6th 1933).

38. The doctrine has been firmly entrenched in the American body of maritimo law since 1903, when Brown, J., definitively surveyed the field of maritime personal injuries in The Osceola, 189 U.S. 158 (1903). See Smith, Liability in the Admiralty for Injutrics to Scamen, 19 HARv. L. REv. 418 (1906). Subsequent Supreme Court decisions approving the principle are collected in Mahnich v. Southern S.S. Co., 321 U.S. 96, 99 (1944). Sce also Seas Shipping Co. v. Sieracki, 328 U.S. 85 (1946).

39. See the early cases collected in Mahnich v. Southern S.S. Co., 321 U.S. 96, 100 (1944), and see further The Tawmie, 80 F.2d 792 (C.C.A.5th 1936); The Cricket, 71 F.2d 61 (C.C.A.9th 1934); Kahyis v. Arundel Corp., 3 F. Supp. 492 (D.Md. 1933); Burton v. Greig, 271 Fed. 271 (C.C.A.5th 1921).

40. The progression may be traced through The Osceola, 189 U.S. 158 (1903); Chelentis v. Luckenbach S.S. Co., 247 U.S. 372 (1918); Carlisle Packing Co. v. Sarldanger, 259 U.S. 255 (1922); Pacific S.S. Co. v. Peterson, 278 U.S. 130 (1928); Cortes v. Baltimore Insular Line, 287 U.S. 367 (1932); Warner v. Goltra, 293 U.S. 155 (1934); The Arizona v. Anelich, 298 U.S. 110 (1936).

41. Socony Vacuum Oil Co. v. Smith, 305 U.S. 424, 428-9 (1939). 
remedy of "unseaworthiness" though the negligence of another had directly caused the accident through use of the imperfect gear. ${ }^{\text {2 }}$ The decision virtually renders the shipowner the absolute insurer of all equipment on the vessel. If there were any doubts, however, as to the authoritative interpretation of the nature of the shipowner's duty of providing "seaworthy" equipment, they were resolved with finality in 1946 by the decision in Sas Shipping Company v. Sieracki.43 The decision is significant in other respects which will be adverted to subsequently, ${ }^{44}$ but of interest here is the statement by the Court that the absolute right to indemnity arises "as an incident, not merely of the seaman's contract, but of performing the ship's service with the owner's consent." 45 In the hierarchy of duties owed seamen by the shipowner, this pinnacle of a "relational" duty existing over and above even strict contractual obligation had been reserved exclusively to the hoary remedy of maintenance and cure. ${ }^{46}$ The decision establishes a simple equation: "Unseaworthiness" = Liability.

42. Mahnich v. Southern S.S. Co., 321 U.S. 96 (1944). MIr. Justice Roberts penned a blistering jeremiad over the sad state to which stare decisis had fallen. The immediate source of his anxiety about the stability of the law lay in the court's express disapproval of Plamals v. Pinar Del Rio, 277 U.S. 151 (1928), to the extent that the older decision did not conform with the decision reached in the later case. It is asserted that the Pinor care holds that no recovery may be had under the doctrine of "unseanorthiness", regardless of the nature of the obligation, if in fact the injury was contributed to by the negligence of a crew member. (Note the legal-level distinction between this admiralty rule which denies any initial liability, and the common-law doctrine of the "fellow servant" which is a defencs to what would otherwise lead to an imposition of liability.) In the Pinar case the mate selected defective rope when there was good rope available; recovery was denied. The case was argued, however, as an action under the Jones Act for neglisence and the particular question raised was whether such an action could be prosecuted in rem. AIr. Justice MeReynolds makes the statement, $i d$. at 155, that the "evidence would not support a recovery upon any other theory," but it may at least be argued that, under the facts, this observation nas gratuitous. The argument in Mr. Justice Roberts' dissent to the Mralmicls case that the statement is not dicta because judges exercise great care not to deliver themselves of opinions not required by the case at bar does not seem convincing. Mahnich v. Southern S.S. Co., supraat 108 .

The case was extensively noted. See 13 Ford L. REv. 132 (1944); 12 GEo. Whasu. L. REv. 361 (1944); 92 U. of P.. L. REv. 459 (1944); 30 V.4. L. REv. 486 (1944).

43. 328 U.S. 85 (19:6).

44. See p. 254 infra.

45. 328 U.S. 85,97 (1946). The court stresses the point repeatedly, id. at 90-7. The question concerned the entitlement of a longshoreman injured on board the ship through defective equipment. Since the stevedore was not by usual contract notions an employee of the vessel, but of an independent contractor, it was necessary that any owner's liability be predicated upon a duty arising from the "status" or "relation" of the injured party.

46. The possible implications of such a new classification are interesting. The logic that held maintenance and cure to be cumulative to other rights to indemnity because its origin is "relational" would require a similar conclusion with regard to seawerthiness and perhaps force the result of election between these ancient remedies, and permit recovery under both the "unseaworthiness" and Jones Act negligence theories. It is not suggested that these results will ensue, but only that the decision in the Sicracki case renders older rationales unconvincing as bases for the distinctions drawn and remedies allowed. 
The infinite possibilities of injury which exist aboard a ship render precedent of negligible assistance in determining what content the courts will pour into the flask labelled "unseaworthiness." 47 Few would have thought that the presence on board of a brutal mate ${ }^{48}$ or a greenhorn untrained sailor would render a ship "unseaworthy"; ${ }^{49}$ or that a seaman would be able to convince a court that he fell in the shower of a docked ship because the soapy floor rendered it "unseaworthy." 50 To the courts has been handed a simple instrument for the imposition of absolute liability with no limitation but judicial conscience.

The Sieracki case not only expanded the liability of the shipowner vertically, so to speak, but extended the scope of the remedy horizontally so as to bring longshoremen within its purview. In reaching this result, the opinion leans heavily upon the fiction created by Mr. Justice Holmes that longshoremen are "seamen" for purposes of suit under the Jones Act." This distortion of common meaning found valid cause when no other remedy lay available to longshoremen, but after the passage of the Longshoremen's and Harbor Workers' Compensation Act ${ }^{52}$ the fiction had lain dormant. ${ }^{63}$ Thus the Supreme Court again has resuscitated an older doctrine calculated to promote the extension of the shipowner's liability, and again, in the word "seaman," the courts are provided with another device for enlarging the scope of the remedy. If, for example, the definition set forth in the Merchant

47. Cases are collected in 1 BENEdict, op. cil. supra note 3 , at $255 \mathrm{n} .34$; Roninson, AdMiralty 303 et seq. (1939); Lord and SPRaGUe, Cases on AdMiralty 337, 349 (1939).

48. The Rolph, 293 Fed. 269 (N.D.Cal. 1923), aff'd, 299 Fed. 52 (C.C.A.9th 1924).

49. The State of Maryland, 85 F.2d 944 (C.C.A.4th 1936), 85 U. of PA. L. REv. 318 (1937).

50. Krey v. United States, 123 F.2d 1008 (C.C.A.2d 1941), 28 VA. L. REv. 649.

51. International Stevedoring Co. v. Haverty, 272 U.S.50 (1926); Jamison v. Encarnacion, 281 U.S. 635 (1930).

52. 44 STAT. 1424 (1927), 33 U.S.C. § 901 (1940).

53. It had been thought prior to the Sieracki decision that the shipowner owed a duty of due care to the longshoremen, whose position was deemed that of the business invitec. E.g., Grasso v. Lorentzen, 149 F.2d 127 (C.C.A.2d 1945), cert. denied, 326 U.S. 743 (1945); The Etna, 43 F. Supp. 303 (E.D.Pa. 1942); The Dalhem, 41 F. Supp. 718 (D.Mass. 1941); The S.S. Anderson, 37 F. Supp. 695 (D.Md. 1941). A full collection of precedents is given in 34 CAL. L. REv. 601, $602 \mathrm{n} .6$ (1946), but the unanimity of these authorities is no longer even persuasive. Following the doctrine of the Sieracki case, see Fodera v. Booth American Shipping Corp., 159 F.2d 795 (C.C.A.2d 1947). But cf. Lauro v. United States, 162 F.2d 32 (C.C.A.2d 1947) (approving Grasso v. Lorentzen doctrine that the owner will not be held liable where the defect was caused by the agents of the independent contractor); Bruszewski v. Isthmian S.S. Co., 66 F. Supp. 210 (E.D.Pa. 1945) (seeking to limit the Sieracki doctrine to longshoremen actually loading and unloading); Bruszewski v. Isthmian S.S. Co., 1947 Am. Mar. Cas. 899 (C.C.A.3d 1947) (refusing recovery where the injury occurred in the removal of a defective boom, the court refusing to declare a constructive warranty of seaworthiness of patently unseaworthy equipment). For a recrudescence of the due carebusiness invitee notion (and an irrational result) see Anderson v. Lorentzen, $160 \mathrm{~F} .2 \mathrm{~d} 173$ (C.C.A.2d 1947) (owner must compensate those stevedores who contracted dermatitis unloading cashew nut liquid unless they contracted it while handling the same leaky drums on the dock). 
Seaman's Act should be adopted as a criterion, there would be no difficulty whatever in extending the doctrine of "unseaworthiness" far beyond its present application. The statute reads". . . every person (apprentices excepted) who shall be employed or engaged to serve in any capacity on board the ... [vessel] ... shall be deemed and taken to be a 'seaman'." 54 And a recent decision permitting a "seaworthiness" recovery by a land carpenter injured on board ship demonstrates that the term "longshoreman" itself may be amazingly elastic. ${ }^{55}$

The scope of the remedy of "unseaworthiness" has never been extended beyond the ship itself. It would be foolhardy to assert that it will not be. Though additional distension might do further violence to the original concept of the remedy, there seems to be no rational policy in permitting a "seaman" to recover absolutely against the shipowner where he is, for example, injured by a falling boom on the ship, but denying this remedy where he is standing on a dock. Jurisdictional difficulties in designating such an injury as a "maritime tort" would be encountered since under admiralty doctrine a dock is an adjunct of the land, ${ }^{56}$ but the expansion of the rights to recovery under the maintenance and cure doctrine ${ }^{57}$ and the recent application of the Jones Act to injuries occuring on land ${ }^{58}$ may well presage a similar development in the doctrine of "unseaworthiness."

Like its companion maritime remedy, maintenance and cure, an action for indemnity under the doctrine of "unseaworthiness" may be instituted by a libel in personam or in rem in admiralty. ${ }^{69}$ Thus a concomitant to the

54. REv. STAT. $\$ 4612$ (1875), as amended, 46 U.S.C. $\$ 713$ (1940).

55. Sulovitz v. United States, 64 F. Supp. 637 (E.D.Pa. 1945). The opinion of the 3d Circuit Court of Appeals in the Sieracki case had already been handed down. The case is interesting further in that an express finding of no negligence was made. The court said the carpenter was a "longshoreman" and therefore the shipowner was liable.

56. Cleveland Terminal R.R. v. Cleveland S.S. Co., 208 U.S. 316 (1908). The implications of an extension of this nature encounter one of the most controversial doctrines in American admiralty law; vis., that admiralty courts have no jurisdiction over torts originating on navigable waters but consummated on land. The Plymouth, 3 Wall. 20 (U.S. 1865). The problem is treated at 1 BENEDICT, op. cit. supra note 3, at 353 et seq.; Robissor;, AdxrRaLty $\$ 9$ (1939); Sprague, The Extension of Admiralty Jarisdiction and the Grouth of Substantive Maritime Law in the United States Since 1835 in 3 LAW, A CENTURr of Progress 294 (1937); Farnum, Admirally Jurisdiction and Amphibious Torls, 43 Yale L. J. 34 (1933); Olverson, Admiralty and the Amphibious Tort Problem, 29 VA. L. Rev. 1010 (1943). Efforts by the admiralty bar associations to induce Congress to override the doctrine of The $P l_{y-}$ mouth and its successors have been unsuccessful to date. See Maritrue LAw Association of the United States Doc. No. 311, Report of Comuittee on Extension of AD:uiRalty JURISDICTION 3149 (May, 1947); 93 Cong. Rec. 4478 (May 1, 1947).

57. Aguilar v. Standard Oil Co. of N.J., 318 U.S. 724 (1943).

58. O'Donnell v. Great Lakes Dredge and Dock Co., 318 U.S. 36 (1943). See p. 261 infra. In effect the decisions of these last two cases at least undermine the rationale of the Plymouth doctrine, though that principle treats primarily of the problems raised by amphibious torts to property rather than the person.

59. The Osceola, 189 U.S. 158, 175 (1903). There have been no subsequent dissents from this proposition. 
extension of the remedy is an expansion of those rights which may be enforced against the vessel itself. The traditional policy which views creation of secret liens with disfavor because of their implications as to merchantability, rights of creditors, ${ }^{60}$ etc., may provide a braking factor countervailing the operation of social considerations tending to expand the scope of the remedy. Any deterrence which such considerations may provide is, however, partially offset by the fact that the availability of the remedy in rem does not imply that all actions will be so prosecuted; for again under the "saving to suitors" clause, the state and federal common law forums are open to the injured seaman who wishes to assert his maritime right in porsonam before a jury. ${ }^{61}$ Furthermore, the Supreme Court's interesting decision in Hendry Co. v. Moore, ${ }^{62}$ that a state may enforce a state law against a maritime res, may indicate that the present majority is not as wary of admiralty proceedings in rem as might be supposed. There are today virtually no observable limits to the doctrine of "unseaworthiness" as a judicial tech. nique for distributing the human losses of the modern economy-and further attenuation may be anticipated.

\section{Statutory Remedies}

Despite paternalistic notions that seamen are "wards of admiralty" and require special protection, ${ }^{63}$ the general maritime law did not extend special dispensations to mariners without exacting a price. Much in the same fashion as modern workmen's compensation schemes represent a bargain between employer and employee, the right to guaranteed compensation being exchanged for immunity from suit, the rights of injured seamen to recover under the doctrines of maintenance and cure and unseaworthiness represented exclusive remedies. The general maritime law simply did not recognize the existence of a right' to recover against an employer under a doctrine of respondeat superior and imputed negligence. ${ }^{64}$ The third of the four famous

60. The argument is persuasively set forth by Chesnut, J., in his dissent in The State of Maryland, 85 F.2d 944, 949 (C.C.A. 4th 1936), and apparently formed at least part of the basis for the refusal of the Supreme Court to permit Jones Act suits to be prosecuted in rem. Plamals v. Pinar Del Rio, 277 U.S. 151 (1928).

61. See p. 244 supra.

62. 318 U.S. 133 (1943).

63. A paragraph on the seaman's hardships is the standard introduction to almost every admiralty personal injury opinion. See, e.g., Reed v. Canfield, 20 Fed. Cas, 426, No. 11,641 (D.Mass. 1832); The City of Alexandria, 17 Fed. 390 (S.D.N.Y. 1883); The Osceola, 189 U.S. 158 (1903); Aguilar v. Standard Oil of N.J., 318 U.S. 724 (1943). The persistency of this paternalistic view regarding seamen is not easily explained. See Jones v. Watcrman S.S. Corp., 155 F.2d 992, 1000 (C.C.A.3d 1946), where a modern court expresses its "opinion that the relationship of the shipowner to the seaman is more closely analogous to that of father and child than to that of an employer to a mere employee."

64. Even the liberal doctrines of Reed v. Canfield, 20 Fed. Cas. 426, 429, No. 11,641 (D.Mass. 1832), recognized that the owners "are not in any just sense liable for consequential damages," and see The City of Alexandria, 17 Fed. 390 (S.D.N.Y. 1883); The Osceola, 
propositions of The Osceola ${ }^{65}$ couches this principle in terms of the fellow servant rule, but since the absence of a negligence cause of action against the shipowner far antedates the articulation of the doctrine of the fellow servant, ${ }^{66}$ the historical accuracy of the explanation may be questioned.

The Merchant Marine Act of $1915^{67}$ was the first statutory attempt to provide injured seamen with a remedy for negligence against the shipowner. Apparently following the statement in The Osceola that the difficulty lay in the fellow servant rule, the Act specifically provided that "seamen having command shall not be held to be fellow servants with those under their authority." 68 Soon after its "uniformity" decision in the Jensen case, the Court was presented with the case ${ }^{69}$ of a seaman injured on navigable waters suing his employer for negligence alternatively under the "saving to suitors" clause and the above quoted section of the new Seamen's Act. In denying recovery on the first ground, Mr. Justice McReynolds reasoned that rights and remedies must be distinguished, that the clause by its terms merely saved a "remedy where the common law is competent to give it" and that therefore a suitor could not invoke a common law right where the matter was maritime. He was entitled to elect to pursue a common law remedy where it was available to enforce a right granted by the general maritime law, but since no right to indemnity on a theory of imputed negligence was recognized in admiralty, the "saving to suitors" clause provided no valid basis for the complaint at bar. ${ }^{70}$ As to the second ground urged, the Court curtly dismissed as "irrelevant" Congress' attempt to meet the fellow servant objection as expounded in The Osceola, since the only rights recognized by the law of the sea were those to maintenance and cure and to indemnity for unseaworthiness, and in these the relation of the master and servant was immaterial. The Act disclosed "no intention to impose upon shipowners the same mea-

189 U.S. 158 (1903); Chelentis v. Luckenbach S.S. Co., 247 U.S. 372 (1918). The state of the law prior to legislative alteration is described in Pacific S.S. Co. v. Petereon, 278 U.S. 130 (1928).

The recognition in The Osceola of the owner's duty to provide a seaworthy ship constituted an adoption of the law as changed by statute in England. 39 \& 40 Vict., c. 80, \& 5 (1876); reenacted $57 \& 58$ VIcr., c. $60, \$ 458$ (1894). But without recognition of a negligence cause of action, the defenses thereto of contributory negligence and assumption of risls were also adopted. See Hedley v. Pinkney \& Sons S.S. Co., [1894] A.C. 222. The actual decision in The Osceole was that no recovery could be had against the owner where the mate had

- given a negligent order. This transmutation of the common law defenses and general tort concepts was noted with alarm at the time of the Osceola decision. Cunningham, Respondeat Superior in Admiralty, 19 HARv. L. Rev. 445 (1906); Cunningham, The Extension to the Admiralty of the Fellow Seriant Doctrine, 18 HARv. L. REv. 294 (1905).

65. 189 U.S. 158,175 (1903).

66. Farwell v. B. \& W. Ry. Corp., 4 Metc. 49 (Mass. 1842); Hough v. Railway Co., 100 U.S. 213 (1879).

67. Act Mar. 4, 1915, c. 153, § 20, 38 Stat. 1185 (1915).

68. Ibid.

69. Chelentis v. Luckenbach S.S. Co., 247 U.S. 372 (1918).

70. Id. at 383-4. 
sure of liability for injuries suffered by the crew while at sea as the common law prescribes for employers in respect of their employees on shore" 71 and therefore plaintiff could not prevail. ${ }^{72}$

\section{The Jones Act}

Thus it was made clear that the only method for permitting injured seamen to recover against the shipowner for negligence was to create a new cause of action and specifically engraft it upon the traditional law of the sea. This the Jones Act did. ${ }^{73}$ Two sentences long, its annotations in the United States Code Annotated cover one hundred and thirty pages. It reads:

"Any seaman who shall suffer personal injury in the course of his employment may, at his election, maintain an action for damages at law, with the right of trial by jury, and in such action all statutes of the United States modifying or extending the common-law right or remedy in cases of personal injury to railway employees shall apply; and in case of the death of any seaman as a result of any such personal injury the personal representative of such seaman may maintain an action for damages at law with the right of trial by jury, and in such action all statutes of the United States conferring or regulating the right of action for death in the case of railway employees shall be applicable. Jurisdiction in such actions shall be under the court of the district in which the defendant employer resides or in which his principal office is located."

The substantive elements of the cause of action granted injured seamen have been fairly well crystallized by twenty-seven years of judicial construction of the Jones Act and thirty-nine years of interpretation of the Federal Employers Liability Act. ${ }^{74}$ The "relational" right to maintenance and cure remains unaffected ${ }^{75}$ the election required being that between an action for indemnity under the doctrine of seaworthiness and an action for negligence under the Jones Act. ${ }^{76}$ Some cases, however, seem to interpret the election

71. Id. at 384 .

72. It is difficult to ascertain just what the majority of the court believed Congress' intent to have been if not to grant the seaman a cause of action grounded upon imputed negligence, since the fellow servant rule was evolved specifically as a defense to that type of action. It is not usual to attribute to the legislature an intent to enact a useless law.

73. 41 STAT. 1007 (1920), 46 U.S.C. \$ 688 (1940).

74. 35 STAт. 65 (1908), 45 U.S.C. $\$ 51$ el seq. A complete discussion of the problems that have been raised and settled under this Act cannot be encompassed within this paper. See 1 BENEDICx, op. cit. supra note $3, \S 25 ; 4 i d$. § 612; RonINson, AdNIRALTY $\S \S 39-44$ (1939). It must be remembered, however, that these excellent treatments were written prior to 1940 , and that a substantial proportion of the statements made therein are todny no longer true, or stand in the shadow of judicial disfavor.

75. Note 20 supra.

76. Note 46 supra. See Roebling's Sons Co. v. Erickson, 261 Fed. 986 (C.C.A.2d 1919), for the rationale of this choice.' Baltimore S.S. Co. v. Phillips, 274 U.S. 316 (1927); Pacific S.S. Co. v. Peterson, 278 U.S. 130 (1928); Smith v. Lykes Bros.-Ripley S.S. Co., 105 F.2d 
clause to mean that the plaintiff may have but one recovery and hold that the plaintiff may allege both grounds in his complaint and is entitled to a reversal if he is forced to elect as between the separate allegations. 7 The action will lie only as against the employer ${ }^{78}$ and by the terms of the statute a showing of negligence of some description constitutes the gist of the action. ${ }^{79}$ The standard of care prescribed is that of the ubiquitous "reasonable

604 (C.C.A.5th 1939) (assigning the nature of the seaworthiness remedy as delictual); Burkholder v. United States, 60 F. Supp. 700 (E.D.Pa. 1945) (an action based on unseaworthiness may not be maintained after a suit under the Jones Act has been dismissed); accord, Plamals v. Pinar Del Rio, 277 U.S. 151 (1928); Wahlgren v. Standard Oil Co. of N.J., 58 F. Supp. 783 (S.D.N.Y. 1944); 1 BENEDICT, op. cit. supra note 3, at 42, 45-6; 4 id. at 199; Rosnsos, ADsrralty $\S 43$ (1939). Acceptance of state workmen's compensation has been held an election and a bar to a Jones Act suit, Owens v. Hammond Lbr. Co., 8 F. Supp. 392 (N.D. Cal. 1934). For a contrary view, see Bay State D. \& C. Co. v. Porter, 153 F.2d 827 (C.C.A. 1st 1946). There a signed release had been given, but since the decision in Garrett v. MooreMcCormack Co., 317 U.S. 239 (1942), the most exacting requirements must be met to render such a release valid. Other recent cases on the point include Stanley v. Weyerhacuser S.S. Co., 1947 Am.Mar.Cas. 411 (Sup. Ct. San Francisco, Cal. 1947); United States v. Johnson, 160 F.2d 789 (C.C.A.9th 1947).

77. German v. Carnegie-IIl. Steel Corp., 1946 Am. Mar. Cis. 1590 (C.C.A.3d 1946); Capillo, 1934 Am. Mar. Cas. 1212 (Sup. Ct. N.Y. 1934). The statement in 4 BEsEdict, op. cit. supra note 3 , at 201, that such a result could not obtain in the federal courts may be discounted. See Seas Shipping Co. v. Sieracki, 328 U.S. 85, 88 (1946), where the Supreme Court shortly dismisses the objection to conducting the seaworthiness suit on the commonlaw side of the court. Cases are collected there. But of. Branic v. Wheeling Steel Corp., 152 F.2d 887 (C.C.A.3d 1945).

78. The point is well settled. See, e.g., The Norland, 101 F.2d 967 (C.C.A.9th 1939); Duarte v. Christie Scow Co., 27 F. Supp. 894 (S.D.N.Y. 1939). Cases are collected in 55 YALE L. J. 584, $586 \mathrm{n} .19$ (1946). The question becomes of interest in attempts to remove suits under the Jones Act. See note 104 infra.

79. Available analyses of this concept of "negligence" are not satisfactory, particularly when considered in conjunction with the now fortified remedy under the doctrine of seaworthiness. The Supreme Court early laid down the principle that it would not be bound by common-law concepts of negligence developed to protect ordinary workers, but would consider the peculiar hazards of the sea and the traditional relations which obtain between the ship owner and the seaman. Cortes v. Baltimore Insular Line, 287 U.S. 367 (1932); $c f$. Alpha S.S. Corp. v. Cain, 281 U.S. 612 (1930). This vague doctrine provides leeway for the finding of "negligence" virtually as desired. See Nowery v. Smith, 69 F. Supp. 755 (E.D.Pa. 1946), aff'd, 161 F.2d 732 (C.C.A.3d 1947), for the most extreme case to date.

However flexible the "negligence" concept under the Jones Act may be, it cannot approach the efficacy of the "unseaworthiness" doctrine as an instrument for imposing liability. Perhaps as a consequence of this, or perhaps because the asserted distinction is without a difference, the Jones Act "negligence" notion and the "unseaworthiness" idea overlap and blend indistinguishably. Compare The Rolph, 299 Fed. 52 (C.C.A.9th 1924), wilh Koehler v. Presque-Isle Tr. Co., 141 F.2d 490 (C.C.A.2d 1944), and Hong v. United States, 59 F. Supp. 794 (S.D.N.Y. 1914) (where brutal seaman aboard, owner held in the first case for sending forth an "unseaworthy vessel," and in the others for "negligence").

Virtually any cause of action may be couched in terms of negligence or unseaworthiness. See, e.g., Krey v. United States, 123 F.2d 1008 (C.C.A.2d 1941) (slippery shower). The situation is further confused by the common law tort concept of "unsafe place to work" and "defective equipment." In Socony Vacuum Oil Co. v. Smith, 305 U.S. 424 (1939), a seaman 
man" ${ }^{80}$ and actions under the Act are treated like any other tort action except insofar as modified by the general rules of admiralty law qualifed by the provisions of the Employers Liability Act regarding permissible defenses.

Though the Supreme Court has had no occasion to deliver an explicit opinion, it seems beyond question that the 1939 amendment of the Employers Liability Act abolishing assumption of risk as a defense ${ }^{81}$ is incorporated by reference into the Jones Act. ${ }^{82}$ The attitude of the present Court toward assumption of risk is reflected by their anticipation of the amendment in rejecting the defense in an action under the Jones Act for negligent failure to provide sound equipment. ${ }^{83} \mathrm{Mr}$. Justice Black's opinion in Tiller v. Allantic Coast Lines, ${ }^{84}$ an action by a railway employee under the amended Em-

was injured on a defective step. The complaint was cast as a Jones Act "negligence" action for "defective equipment." The case arose prior to the 1939 amendment to the Employers Liability Act abolishing assumption of risk as a defense. In an opinion not remarkable for its clarity, the Court, at least without explicit recognition of its technique, held that assumption of risk was not a valid defense to an action for "negligence" in providing "defective equipment" because it could find no clear precedent which permitted it as a defense to an action for an "unseaworthy" vessel. Similar mergers of these originally disparate ideas are common. See Hendriksen v. City of Chicago, 330 Ill. App. 141, 70 N.E.2d 848 (1947), where the alleged gravamen is negligence in not providing a "safe place to work" where a fireman was not furnished with goggles.

The optimum in confusion is reached by those cases which speak of the owner's "negligence" in not providing a "seaworthy" vessel. E.g., Miller v. Wessel, Duvall \& Co., Inc., 1947 Am. Mar. Cas. 429 (S.D.N.Y. 1946); American Pac. Whaling Co. v. Kristensen, 93 F.2d 17 (C.C.A.9th 1937).

A distinction has been made through historical accident which cannot be borne out in practice. But on the basis of the distinction different legal incidents have been attached. As a consequence a difference between absolute liability and "negligence" liability will turn upon the phraseology of the complaint. If the position of the Sieracki case is taken, it is difficult to see why injured parties should seek to prove "negligence" in not providing a seaworthy vessel when a change of wording will entitle them to recovery merely for showing the "unseaworthiness". The Sieracki case approves jury trial for these actions, and additional incentive lies in the fact that only laches serves as a bar to the admiralty suit. Judicial fiat acting upon the seaworthiness doctrine has to a considerable degree remedied the evil which the Jones Act was designed to cure, and has done so more effectively.

80. This is the usual statement, and clearly would seem to represent the intent of the statute. It would seem, however, that the reasonably prudent landlubber is less cautious than an equally circumspect man of the sea. Note 79 supra.

81. 53 Stat. 1404 (1939), 45 U.S.C. \& 54 (1940).

82. There still seems to be some doubt as to whether the Jones Act incorporates all amendments affecting the rights of railroad workers, though there is little authority at all. Research has disinterred but one case which relies explicitly upon this statutory abolition of the assumption of risk. Roberts v. United Fisheries Vessels Co., 141 F.2d 288 (C.C.A.1st 1944), cert. denied, 323 U.S. 753 (1945). Cf. Roberts, J., dissenting in Mahnich v. Southern S.S. Co., 321 U.S. 96, 105 (1943) (amendment as to statute of limitations is adopted into the Jones Act). Benedict seems to be of the opinion that the Jones Act incoporates only those rights of railway workers held as of 1920 . 4 BENEDicr, op. cit. supra note 3 , at 205 . See note 105 infra.

83. Socony Vacuum Oil Co. v. Smith, 305 U.S. 424 (1939).

84. 318 U.S. 54 (1943). 
ployers Liability Act, also makes it very clear that the Court will not tolerate the outlawed defense to re-enter under the guise of "no negligence." Mr. Justice Frankfurter, concurring, sought to make clear the distinction between "assumption of risk" of the employer's negligence and "assumption of risk" of ordinary occupational hazards unaggravated by the employer's negligence. ${ }^{85}$ This distinction would seem entirely valid so long as recovery is not to be predicated upon absolute liability, and recent federal cases indicate that the seaman still assumes the ordinary risks of his employment. ${ }^{85} \mathrm{It}$ may be noted, however, that "assumption of risk" in any form seems anathema to the majority of the Court, and that Mr. Justice Frankfurter concurred alone.

The essential character of the proceeding as prescribed by the Act renders it a less convenient instrument for adaptation to altering social objectives than the relational or contractual obligations of the general maritime law. Where, by one construction or another its terms have been extended, anomalies and internal inconsistencies seem to have resulted through the interaction of the other remedies which are available to injured maritime workers. It had seemed definitely settled that the ambit of the Jones Act remedy embraced only injuries occurring on navigable waters. ${ }^{57}$ But in $O^{\prime}$ Donnell v. Great Lakes Dredge and Dock Company ${ }^{85}$ a seaman ordered ashore to perform certain duties was injured in the vicinity of the ship; the Court held, partly on analogy to its recent decision that an action for maintenance and cure could be maintained though the injury occurred on shore leave, that the tort was still essentially maritime ${ }^{89}$ and that the plaintiff was entitled to bring an action under the Jones Act. Though the decision marks a radical departure from pre-existing doctrine, no rational reason is discernible why the conclusion should be otherwise. However, like the Employers Liability Act, the Jones Act, where applicable, has been held to be exclusive as against remedies provided by state law, even though no employer's negligence can be shown to have caused the injury and hence no recovery can be had.?

85. Id. at 68 .

86. Bovich v. United States, 70 F. Supp. 482 (N.D.Cal. 1947); Roberts v. United Fisheries Vessels Co., 141 F.2d 288 (C.C.A.1st 1944). But cf. Hendriksen v. City of Chicago, 330 Ill. App. 141, 70 N.E.2d 848 (1947); Denesha v. Lake Chelan S.S. Co., 1937 Am. Mar. Cas. 1013 (W.D.N.Y. 1937). Loose language to the effect that the seaman assumes no risks means, of course, absolute liability of the shipowner for all injuries. The result is never couched in these terms where it is the actual question, however, resort being more easily made to the label of "unseaworthiness" where recovery is permitted, and Mr. Justice Frankfurter's distinction being cited where recovery is denied.

87. The Montezuma, 15 F.2d 580 (W.D.N.Y. 1926); 1 BENEDict, op. cil. supra note 3, at 48, n. 52, 53; 4 id. at 206; RoBInson, AdMIRALTY $\S 42$ (1939).

88. 318 U.S. 36,43 CoL. L. REv. 504 (1943).

89. The Court avoided the jurisdictional problem discussed in note 56 supro by rejecting the locality test and founding admiralty jurisdiction upon the maritime nature of the service, status, and relationship of the injured seaman. The decision drives a large wedge into the Plymouth doctrine, apart from its specific significance to maritime personal injury law.

90. Northern Coal and Dock Co.v. Strand, 278 U.S. 142 (1928). Sec Employers' Lia- 
Seamen injured ashore have formerly had recourse to the remedies provided by the state's local laws, ${ }^{91}$ and the Supreme Court has approved such recovery since there was "no pertinent federal statute." ${ }^{92}$ Whether the state laws have now been superseded through the extension of the Jones Act remedy to shore injuries or whether the "exclusive remedy" decisions are to be deemed overruled sub silentio is an unresolved question. There are indications that this particular expression of traditional judicial benevolence toward seamen may prove a boomerang. ${ }^{93}$

The very recent case of Nowery v. Smith, ${ }^{94}$ though exceptional in its factual context and to that extent limited in its implications, demonstrates how the Court's new arguments may be combined to achieve a startling result. There a seaman drinking beer in a barroom was assaulted by the chief engineer's mate of his own ship, and brought suit against his employer for indemnity under the Jones Act and for maintenance and cure. The court reasoned that under the Waterman doctrine the injured mariner was "in the service of the ship" and clearly entitled to maintenance and cure; that, by the same token, a seaman engaging in the traditional mariners' technique of rehabilitation was thereby acting "in the course of his employment"; that the O'Donnell rule permits the suit though the injury occur on land; and that the shipowner must be held liable on grounds of negligence in employing upon his ship an engineer of such brutal and callous nature. The decision vitiates the "course of employment" requirement prescribed by the Jones Act. If followed, it also renders any injury ashore "maritime" 95 and compounds the difficulties of adjusting state and federal law.

bility Assurance Corp. v. Cook, 281 U.S. 233, 237 (1930) (concurring opinion by Stone, J.); cf. Erie R. Co. v. Winfield, 244 U.S. 170 (1917); N.Y. Central R. Co. v. Winfield, 244 U.S. 147 (1917). Cf. futther Lindgren v. United States, 281 U.S. 38 (1930); Panama R. Co. v. Johnson, 264 U.S. 375 (1929); Frame v. City of New York, 34 F. Supp. 194 (S.D.N.Y. 1940); RoBinson, Adsiralty 316 (1939).

91. Esteves v. Lykes Bros. S.S. Co., 74 F.2d 364 (C.C.A.5th 1934); Kulczyk v. Rockport S.S. Co., 8 F. Supp. 336 (E.D.Mich. 1934); O'Brien v. Calmar S.S. Co., 104 F.2d 148 (C.C.A.3d 1939), cert. denied, 308 U.S. 555 (1939). A standard common-law cause of action against the shipowner lay, however, for the injury on the land. Mullen v. Easter Tr. Co., 25 F. Supp. 62 (E.D.Pa. 1938).

92. State Ind. Comm'n of N. Y. v. Nordenholt, 259 U.S. 263, 276 (1922).

93. This possibility is no longer hypothetical. The Betsy Ross, 145 F.2d 688 (C.C.A. 9th 1944); Ruljanovich's Case, 1944 Am. Mar. Cas. 102 (D. Ct. App. Cal. 1943) (fisherman injured while getting nets from warehouse held to be in maritime activity and within scope of Jones Act; state compensation award annulled, and cross appeal alleging negligence under Jones Act dismissed as unsupported); Johnson v. Harms Co., 1946 Am. Mar. Cas. 1555 (C.P.N.J. 1946) (barge captain ashore buying provisions struck by auto; state compensation denied because the state law cannot apply to "maritime torts"). If these cases are followed, and the seaman now carries a Midas' touch that renders all his accidents cognizable by the admiralty court, it is clear that compensation as against his employer is out of the question unless he is cautious to be injured by a fellow servant.

94. 69 F. Supp. 755 (E.D.Pa. 1946), aff'd, 161 F.2d 732 (C.C.A.3d 1947).

95. The cases at note 93 , supra, do not seriously discuss the maritime nature of the injury, but merely seem to assume that the extension of the Jones Act remedy thereby pre- 
The fiction that longshoremen are "seamen" 20 has suddenly been resuscitated by the Sieracki decision. ${ }^{97}$ Displaying that largeness of mind which is not dismayed by the hobgoblin of consistency, the Supreme Court on the very day the Sieracki opinion was rendered, refused to permit a longshoreman to sue under the Jones Act where he was injured on the dock (land) by a life raft fallen from the ship, even though under the $O$ 'Donnell decision, a "seaman" injured ashore could have brought suit." The longshoreman, as the law now stands, would thus seem to be a "seaman" for purposes of suit under the Jones Act, so long as he is careful to be hurt aboard ship." Other "seamen" may be injured where they please. Query the stevedore injured on the dock who brings suit under the seaworthiness doctrine? If such an action is permitted, the doctrine of seaworthiness is extended to land injuries. If not, will the "uniformity" of the nation's admiralty law be jeopardized by the continued application of state remedies to "seamen"? It is difficult to ascribe the present disorder and tenuous distinctions to inevitable principle or rational policy.

Certain procedural aspects of the Jones Act are settled beyond question. ${ }^{100}$ The rights under the Act may not be enforced in rem, ${ }^{101}$ though they may be enforced by a libel in personam on the admiralty side of the court ${ }^{102}$ since

cludes application of the state remedy. The Jensen doctrine, of course, underlies the entire problem.

96. International Stevedoring Co. v. Haverty, 272 U.S. 50 (1926); Buzynski v. Luckenbach S.S. Co., 277 U.S. 226 (1928); Northern Coal \& Dock Co. v. Strand, 278 U.S. 142 (1928); Jamison v. Encarnacion, 281 U.S. 635 (1930) (injury occurred in 1925); Uravic v. Jarka Co., 282 U. S. 234 (1931) (injury in 1926). The courts have been consistently troubled with the problem of ascertaining who is a seaman for purposes of suit under the Jones Act. Some of the results have been interesting. See Robinson, The Seaman in American Admiralty Law, 16 B.U.L. REv. 283 (1936), where the cases are collected.

97. Writing without benefit of the Supreme Court's decision in Seas Shipping Co. v. Sieracki, 328 U.S. 85 (1946), Professor Robinson and some courts were of the opinion that the fiction had ceased to have operative existence. RoBIssos, ADsIRaLTY $\$ 40$ (1939); Nogueira v. New York, N. H. \& H. R. Co., 32 Fed. 179, 181 (C.C.A.2d 1929); Lawson v. Maryland Casualty Co., 94 F.2d 193 (C.C.A.5th 1938).

98. Swanson v. Marra Bros., 328 U.S. 1 (1946). The arguments of the case are not entirely persuasive if the reasoning of the $O^{\prime}$ Donnell and Horerly cases are accepted. The court at least implies that a factor in the decision lies in the gearing of the $O^{\prime}$ Donnell decision to the crew member's right to maintenance and cure. It seems clear that the longshoreman has no claim to this remedy. See note 28 supra.

99. The longshoreman's character as a "seaman" is apparently not sufficiently perrasive to permit him to pursue a remedy in the federal courts without filing bond as is permitted to "seamen" under 40 STAT. 157 (1917), as amended, 40 Srat. 683 (1918), 28 U.S.C. $\$ 837$ (1940). Raccuglia v. United States, 66 F. Supp. 769 (E.D.N.Y. 1946); DiStefano v. Ropner \& Co., 57 F. Supp. 517 (S.D.N.Y. 1944).

100. The procedural aspects of an action under the Jones Act are treated extensively in the leading treatise at 4 BENEDICT, op. cil. supra note $3, \S 612$; sed catcal lector.

101. Plamals v. Pinar Del Rio, 277 U.S. 151 (1928); see cases assembled in 1 BENEDICT, op. cit. supra note 3 , at 44 n. 39 .

102. Baltimore S.S. Co. v. Phillips, 274 U.S. 316 (192i). Consult 1 BENedict, op. cil. supra note 3 , at 44 n. 38 . 
indemnity for negligence is now a maritime right. The terms of the statute provide for jury trial, and this may be obtained either in the state courts or on the common-law side of the federal court. ${ }^{103}$ Though some early cases were contra, it is now clear that the provision of the Employers Liability Act prohibiting removal of a suit to the federal court is also applicable to suits under the Jones Act, ${ }^{104}$ and it now seems established that the statute of limitations of three years under the 1939 amendment of the Employers Liability Act also applies to the Jones Act. ${ }^{105}$

The ambiguous interlacing of both venue and jurisdiction concepts in the last sentence of the Act has, however, been the source of constant difficulty. Following the Supreme Court's construction that the word "jurisdiction" as used here really means "venue", 106 the further doctrine has developed that

103. Id. at 44 n. 37. Under the Jensen doctrine the principles applicable remain constant irrespective of forum.

104. The principle is now agreed upon. Fiolat v. Minnesota-Atlantic Tr. Co., $31 \mathrm{~F}$. Supp. 219 (D. Minn. 1940); Note, 21 OrIo Ops. 308 (1941). Difficulties are encountered in its application, however. During the war considerable question arose as to the legal relations of seamen on ships owned by the United States but being operated by private general agents. The agent companies attempted to remove Jones Act suits brought against them on the ground that they were not employers of the injured seamen, and that they could not be sued under the Jones Act, and that, therefore, the suits could be removed as a normal suit where the jurisdictional requisites are present. Since in many cases the only real issue involved was the establishment of the employer-employee relationship, such a maneuver, if successful, provided a non-jury adjudication of the case in a forum other than that of the plaintiff's choosing. The problem is well analysed in Gunderson v. Barber Asphalt Corp., 71 F. Supp. 40 (E.D.N.Y. 1947), where the court refused to go beyond the face of the complaint to inquire into a "decisional" fact, though it would examine, e.g., the validity of an allegation of diversity since such averment concerns only a "jurisdictional" fact. Contra: Steele v. American South African Line, 62 F. Supp. 636 (N.D.Cal. 1945); Baker v. MooreMcCormack Lines, 57 F. Supp. 207 (N.D.Cal. 1944); $c f$. Shantz v. American Dredging Co., 138 F.2d 534 (C.C.A.3d 1943).

The particular problem has been solved by the decision of the Supreme Court that the general agent may be considered the employer for purposes of suit under the Jones Act. Hust v. Moore-McCormack Lines Inc., 328 U.S. 707 (1946). But the extent to which the district court will examine the complaints on remand petition remains unclarified.

105. 53 StaT. 1404 (1939), 45 U.S.C. $\$ 56$ (1940). Keil v. United States, 65 F. Supp. 431 (D.Md. 1946); Royle v. Standard Fruit \& S.S. Co., 269 App. Div. 762, 54 N.Y.S.2d 778 (2d Dep't 1945); Streeter v. Great Lakes Transit Corp., 49 F. Supp. 466 (W.D.N.Y. 1942). Whether the limitation merely cuts off the remedy or totally extinguishes the right is not entirely clear. Compare Roeper v. American Pres. Lines, 1947 Am. Mar. Cas. 452 (Sup. Ct. San Francisco, Cal. 1947), with Osbourne v. United States, 1947 Am. Mar. Cas. 930 (S.D. N.Y. 1947) (American seamen injured just before being made Japanese prisoners of war for the duration of hostilities; the former opinion finding that the time does not start to run until access to the court is possible, the latter holding the limitation absolute). A possible third rationale is represented by Crescitelli v. United States, 66 F. Supp. 894 (E.D.Pa. 1946) (the limitation termed "jurisdictional" and complaint brought after three year period dismissed for lack of jurisdiction).

106. Panama R.R. Co. v. Johnson, 264 U.S. 375 (1924). The Court was fearful of constitutional difficulties possible if the Jones Act were construed to permit these actions to be tried only on the law side of the court, since they are "maritime." The "saving to suitors" 
this "limitation" of "venue" applies only to actions brought on the commonlaw side of the federal courts. ${ }^{107}$ Thus, on the admiralty side of the court, though the right to indemnity may not be brought in rem, valid service on the defendant may be made by foreign attachment, the "jurisdiction' (venue) clause being wholly irrelevant. ${ }^{103}$ Beyond this, the cases are in irreconcilable conflict on the jurisdictional and venue requisites for sustaining a Jones Act proceeding on the common-law side of the United States courts. ${ }^{109}$

clause then permits them to be instituted in the state courts, and since the "jurisdictional' sentence of the Act could obviously have no application to state proceedings, the Court felt that it was necessary to reduce the sentence to a venue provision, raivable by the defendant. Bainbridge v. Merchants \& Miners Transp. Co., 287 U.S. 278 (1932). It is suggested that the conclusion is not forced by the argument. See note 109 infro.

107. Arthur v. Compagnie Generale Transatlantique, 72 F.2d 662 (C.C.A.5th 1934) (distinguishable as being a Canal Zone case); McDaniel v. Baker Sand \& G. Co., 24 F.2d 987 (S.D.Ala. 1928); Evans v. Nicholson Transit Co., 1947 Am. Mar. Cas. 687 (N.D.Ohio 1944); Bennett v. Standard Oil Co. of N.J., 33 F. Supp. 871 (D.MId. 1940); MIcKola v. McCormick S.S. Co., 24 F. Supp. 378 (N.D.Cal. 1938); Eckert v. Socony Vacuum Oil Co., 13 F. Supp. 342 (E.D.Pa. 1935). Contra: Joralemon v. South Atlantic S.S. Co., 39 F. Supp. 116 (S.D.N.Y. 1941); The M. E. Farr, 38 F. Supp. 8 (W.D.N.Y. 1940); Pomona, 1938 Am. Mar. Cas. 1357 (S.D.Cal. 1938); Bannon v. Seaboard Air Line Ry. Co., 52 F.2d 886 (S.D. Ga. 1930).

108. Brown v. C. D. Mallory \& Co., 122 F.2d 98 (C.C.A.3d 1941), 51 YALE L. J. 869 (1942).

109. The language employed in the last sentence of the Act allows of a number of possible constructions. The simplest view that could be taken is that the statute means what it says in granting "jurisdiction" to the district court of the district wherein defendant resides or has his principal office, regardless of the presence of other grounds of federal jurisdiction. A few cases seem willing to permit the clause to do double duty in this fashion. Lindquist $v$. Dilkes, 127 F.2d 21 (C.C.A.3d 1942); Van Camp Sea Food Co. v. Nordylse, 140 F.2d 902 (C.C.A.9th 1944), cert. denied, 322 U.S. 760 (1944); Kuhlman v. Fletcher Co., 20 F.2d 465 (C.C.A.3d 1927); cf. McDonald v. Cape Cod Trawling Co., 71 F. Supp. 888 (D.Mass. 1947); Peters v. Detroit Nav. Co., 24 F.2d 454 (IW.D.N.Y. 1927) semble.

The Dilkes case is not squarely in point, for the decision actually made is that an action for maintenance and cure is within the jurisdiction of the District Court where joined with a Jones Act suit, though the latter be dismissed, but the decision assumes the original jurisdiction over the Jones Act suit.

A second possible construction is that the sentence is a designation of venue only and that, in addition, there must be independent grounds for federal jurisdiction. Adopting this view, some courts have taken the position that the Act creates a genuinely maritime cause of action and thus independent grounds of jurisdiction are found in U.S. CovST. Art III, $\S 2$, and 28 U.S.C. $\$ 41$ (a) (1940). McMenamin v. McCormick S.S. Co., 37 F. Supp. 908 (N.D. Cal. 1941); see Baltimore S.S. Co. v. Phillips, 274 U.S. 316, 324 (1927); Sevin v. Inland Waterways Corp., 88 F.2d 988, 989 (C.C.A.5th 1937); Mullen v. Easter Trans. Co., 25 F. Supp. 62 (E.D.Pa. 1938).

Other courts have said that the independent grounds of jurisdiction are found in the existence of a suit arising under the laws of the United States and accordingly have required the jurisdictional amount of $\$ 3,000$. Rowley v. Sierra S.S. Co., 48 F. Supp. 193 (N.D. Ohio 1942), 56 HARv. L. Rev. 1161 (1943); see Panama R.R. Co. v. Johnson, 264 U.S. 375, 383-4 (1924) (it would appear to the writer that this statement by the Supreme Court is conclusive, but the citation is seldom relied upon); Smith v. Nicholson Univeral S.S. Co., 42 F. Supp. 1001 (W.D.N.Y. 1941) semble; Branic v. Wheeling Steel Corp., 152 
The unfortunate nature of this state of affairs is underscored by the tendency to dismiss the complaints rather than transfer them to the admiralty docket. Additional complexities are introduced where the complaint combines causes

F.2d 887 (C.C.A.3d 1945), discussed at note 110 infra. The opinion in the Rozvley case is extremely confused, but it seems that the $\$ 3,000$ is needed because this is essentially a law action, this modern court being persuaded by the fact that the complaint is not called a "libel." Query the result if the action had been found to be essentially a maritime cause?

Cases which seem to occupy some indeterminate middle ground include Nolan v. General Seafoods Corp., 112 F.2d 515 (C.C.A.1st 1940); Stevens v. R. O'Brien \& Co., 62 F.2d 632 (C.C.A.1st 1933).

The final group of cases are those which attach no significance either to the statutory or maritime character of a Jones Act suit, and, considering it as any other action, require the usual diversity and jurisdictional amount. Lima v. Burbank, $1946 \mathrm{Am}$. Mar. Cas. 1524 (S.D.N.Y. 1946) (complaint dismissed for lack of diversity). But, except for Erlich v. Wilhelmson, 44 F. Supp. 414 (E.D.N.Y. 1942)-a laconic opinion in accord-the cases upon which the court relies to support its conclusion are not convincing. The Rowley case, supra, is cited, but that concerns only the jurisdictional amount and accepts the "federal question" ground for jurisdiction. Modin v, Matson Nav. Co., 128 F.2d 194 (C.C.A.9th 1942), cited in the Lima case, concerned the transfer to the admiralty side of the court of a claim for maintenance and cure after the Jones Act claim had failed of substantiation by the evidence and been dismissed. This decision would actually imply a position contrary to the purpose cited. Note too that even the refusal to entertain the maintenance claim is supported only by Benedict, who gives no authority. The Limea decision also refers to Stamp v. Union Stevedoring Co., 11 F. 2d 172 (E.D.Pa. 1925), but in that case it is not at all clear that the injury under discussion is even maritime; the Jones Act is not mentioned as the grounds for the suit; and further, the court says only that "the usual jurisdictional" requirements must be met even in admiralty causes of action; diversity of citizenship represents but one of these general bases for federal jurisdiction. Phila. \& R. R. Co. v. Berg, 274 Fed. 534 (C.C.A.3d 1921), cert. denied, 257 U.S. 638 (1922), was an action for unseaworthiness and stands only for the proposition that the "saving to suitors" clause permits such actions to be maintained on the civil side of the federal courts where the jurisdictional requirements are present. Cf. Ross v. Pacific S.S. Co., 272 Fed. 538 (D.Ore. 1921), where a similar suit is remanded to the state court for lack of the jurisdictional amount.

However poorly supported, there are now two square decisions in the New York fedcral courts to the effect that diversity of citizenship is necessary to form a basis for a Jones Act suit. It is submitted that perfectly acceptable bases for jurisdiction may be found without having to resort to this aberrational and unfortunate position.

Other procedural incidents of a Jones Act suit remain unclarified. A few cases have tackled the problem of the application to such an action of REv. STAT. $\$ 968$ (1875), 28 U.S.C. $\$ 815(1940)$, which denies costs to the plaintiff unless the amount in dispute exceeds \$500. In McMenamin v. McCormick S.S. Co., 37 F. Supp. 908 (N.D.Cal. 1941), the statute was held inapplicable. Contra: Goldberg v. Atlantic Transport Co., 1939 Am. Mar. Cas. 462 (S.D.N.Y. 1939); Palm v. Grace Lines, 1936 Am. Mar. Cas. 1053 (S.D.N.Y. 1936).

The application of the Jones Act to alien seamen has caused some difficulties. The Act has latterly been held to permit suit by a foreign seaman injured on a foreign vessel. Kiyriakos v. Goulandris, 151 F.2d 132 (C.C.A.2d 1945). It had seemed settled to the contrary, but the majority distinguished the case at bar by the fact that the articles were signed in the United States. Hand, J., was unable to see the distinction. Subject to this possible new qualification, the old rule still seems to be applied. O'Neill v. Cunard White Star, 160 F.2d 446 (C.C.A.2d 1947); Puig v. Royal Norwegian Gov't, 72 F. Supp. 69 (S.D.N.Y. 1947).

The jurisdictional difficulties raised by the special situation where the United States is the shipowner is not within the scope of this study. See Hust v. Moore-McCormack Lincs, 
of action; 110 for district courts are under a disability to conduct a "hybrid" common-law-admiralty trial, part to the court and part to the jury, ${ }^{111}$ though they are quite capable of doing this under the new Federal Rules when sitting as a common-law-equity court.

In view of the remedial nature of the Jones Act, and the usually benign attitude of the courts in their treatment of the rights of seamen, it seems highly undesirable to surround the federal statutory remedy by a maze of conflicting jurisdictional barriers.

\section{The Federal Longshoremen's and Harbor Workers' Act}

Following the declaration by the Supreme Court that the states' workmen's compensation acts could not apply to maritime injuries, because such legislation would work "material prejudice to the characteristic features of

328 U.S. 707 (1946), reversing 176 Ore. 662, 158 P.2d 275 (1945); Note, Remedies of 2ferchant Seamen Injured on Goternment Oconed Vessels, 55 YaLE L. J. 584 (1946); 34 GEo. L. J. 367 (1946). The doctrine of the Hust case must now be considered limited by the later decision in Caldarola v. Thor Eckert Co., 67 Sup. Ct. 1569 (1947). There the court held that though the Hust case renders the general operating agent an "employer" liable to suit under the Jones Act, he is not to be considered responsible for torts to third parties. This tenuous. and dubious structure was erected against the dissent of four of the Justices. The situation: as respects remedies against the government has also been modified by American StevedoreCo. v. Porello, 67 Sup. Ct. 847 (1947). The case corrected the long standing misapprehension that suit for maritime personal injuries or death may be brought against the government only under the Suits in Admiralty Act, 41 STAT. 525 (1920), 46 U.S.C. $\$ \$ 741-50$ (1940), 39 YALE L. J. 1189 (1930); for the decision holds that the Public Vessels Act, 43 STAT. 1112 (1925), 46 U.S.C. $\$ 781$ (1940), also provides a proper remedy for torts by public. vessels to the person and not just to property.

110. The problem of proper venue is complicated by the variant federal venue provisions geared to different grounds of jurisdiction. Branic v. Wheeling Steel Corp., 152 F.2d 887 (C.C.A.3d 1945), illustrates the issue. There action was instituted in plaintifi's district alleging "unseaworthiness" and negligence under the Jones Act. The jurisdictional ground" for the former, brought by virtue of the "saving to suitors" clause, was diversity; and thus. venue was proper either in plaintiff's or defendant's district. 49 Star. 1213 (1936), 28. U.S.C. $\$ 112$ (1940). Since jurisdiction was not based upon diversity alone, however (the court apparently recognizing the "federal question" source of jurisdiction over the Jones Act suit), the venue was held improper and the case remanded with orders to dismiss unless the Jones Act allegations were withdrawn. The conflicts between this analysis and that which holds forced election to be error is apparent.

For authority that a Jones Act suit against the employer may be tried together with a suit against the third party tort feasor see Psaroumbas v. United Greek Shipowners Corp., 1946 Am. Mar. Cas. 581 (S.D.N.Y. 1946). Contra: Ginsburg v. Standard Oil Co. of N.J., 1946 Am. Mar. Cas. 109 (S.D.N.Y. 1945).

Efforts are being made to restrict the venue provisions of the Employers Liability Act; and H.R. 1639 regarding the matter has passed the House of Representatives. 93 CoxG. REc. 7497 (June 19, 1947), 7537 (June 20, 1947), 9276 (July 16, 1947), 9353, 9369 (July 17, 1947), 9415 (July 18, 1947). The effects of the bill upon the dependent Jones Act seem not to have been discussed.

111. See Kuhlman v. Fletcher Co., 20 F.2d 465, 467 (C.C.A.3d 1927); MIcDonald v. Cape Cod Trawling Co., 71 F. Supp. 888, 892 (D.Mass. 1947). 
the general maritime law," 112 Congress twice amended the Judiciary Act in an attempt to authorize the states to include maritime workers within the purview of their compensation schemes. ${ }^{113}$ Both amendments were stricken down as representing an unconstitutional delegation of legislative power, ${ }^{114}$ the Court, however, hinting broadly that a federal statute applying uniformly throughout the nation would be a valid exercise of the federal legislative power over matters maritime. ${ }^{115}$ The implication was not lost, and in 1927 there was enacted the Federal Longshoremen's and Harbor Workers' Compensation Act. ${ }^{116}$

The substantive aspects of the Act are in no way extraordinary, and like all such statutes, the administrative machinery provided is admirable for its simplicity. ${ }^{117}$ Compensation according to a fixed schedule is paid by the employer where one within the coverage of the Act is injured; ${ }^{118}$ the remedy is exclusive as against the employer, except that where he fails to make payment, suit at law or admiralty may be instituted. ${ }^{119}$ This provision virtually emasculates the holding that longshoremen are "seamen" for purposes of a suit under the Jones Act, for the compensation statute, where applicable, represents an exclusive remedy as against the employer while an action under the Jones Act may be instituted only against an employer. Under recent decisions, the election to sue a third party is not foreclosed by the acceptance of compensation, a formal award being necessary to constitute a bar. ${ }^{120}$

The difficulties encountered in administration of the Act, however, derive from the peculiar conditions which determine the scope of its application. In general it applies to all maritime workers injured on navigable waters, but this is subject to two large exceptions. At their request, masters and crew members were expressly excluded from the operation of the Act. ${ }^{121}$ The

112. So. Pac. Co. v. Jensen, 244 U.S. 205, 216 (1917).

113. 40 Stat. 395 (1917); 42 Stat. 634 (1922).

114. Knickerbocker Ice Co. v. Stewart, 253 U.S. 149 (1920); State of Washington v. Dawson \& Co., 264 U.S. 219 (1924).

115. Id. at 227.

116. 44 Stat. 1424 (1927), as amended, 52 Stat. 1164 (1938), 33 U.S.C. $\$ 900-50$ (1940).

117. The provisions of the Longshoremen's Act are well presented at 1 BENEDICT, op. cit. supra note 3, §§ 27, 141c-147; 4 id., $\S \S 628-643$; RoBINSON, ADMIRALTX $\$ 15$ (1939).

118. 44 StaT. 1424 (1927), as amended, 52 STAT. 1164 (1938), 33 U.S.C. $\$ \$ 908-9$ (1940).

119. Id. $\$ 905$.

120. American Stevedores, Inc. v. Porello, 67 Sup. Ct. 847 (1947), settles the matter. See Ruggiero v. Norwegian Shipping \& Trading Mission, 49 N.Y.S.2d 700 (Sup. Ct. 1944), however, where suit is dismissed against the third party tort feasor under the state rule that acceptance of compensation bars suit. If this decision is accepted such actions must be brought only in the federal courts. The implications of the Jensen doctrine would seem to be in direct conflict.

121. Like the Railway Brotherhoods, the seamen were better pleased with the larger awards possible under the modified common-law suit under the federal statutes. See Nogueira v. New York, N. H. \& H. R. Co., 281 U.S. 128, 136 (1930). And see the Congressional Committee reports in footnotes to Crowell v. Benson, 285 U.S. 22 (1932). The arguments are pursuasively presented in a statement by Andrew Furuseth in AxTELL, MERchanT SEAMEN's Law 75 (1943). 
second limitation derives from Congressional malleability at the hands of a demanding Supreme Court. Fearful of exceeding its constitutional mandate, Congress sought the limited objective of drafting a buffer statute designed to provide a remedy interstitial to the existing maritime remedies and the remedies provided by state law. Under the "maritime but local" doctrine developed by the Supreme Court as a limitation upon the stricture of the Jensen decision, state law was free to operate with regard to matters maritime where it wrought no material prejudice to the essential "uniformity" of the general law of admiralty. ${ }^{122}$ The Longshoremen's Act incorporates this nebulous concept and excepts from its coverage all injuries compensable under state law. ${ }^{123}$

Thus a new statutory remedy was sandwiched in among the admiralty doctrines, the Jones Act, and the state laws, applicable wherever it is found that a "maritime worker" who is not a "master or crew member" ${ }^{2 e s}$ suffers an "accident arising out of and in the course of employment" where the injury occurs on "navigable waters" but is not covered by state law, i.e., is not "maritime but local." It would be difficult to construct a more unpredictable series of definitional tests. State compensation acts encounter sufficient difficulty in assessing whether the injury was an "accident arising out of and in the course of employment"; the federal statute requires three other tests of equal vagueness and a fourth, the "maritime but local" criterion, which has absolutely no relevance to fact. The decisions attempting to segregate matters "maritime" from those "maritime but local" are completely irreconcilable, and understandably so. ${ }^{125}$

It was inevitable that in some instances suitors should be unable to outguess the decision on all of the "tests" and be barred by a statute of limitations from pursuing another remedy, or should remain remediless where both the state and federal commissions deny jurisdiction. ${ }^{103}$ The AlphonseGaston provision in many state statutes limiting their application to those injuries not covered by the federal statute gives rise to a jurisdictional test defined in terms of itself and tends to increase the chances of mutual disclaimer of jurisdiction. ${ }^{127}$

122. Western Fuel Co. v. Garcia, 257 U.S. 233 (1921); Grant Smith-Porter Ship Co. v. Rohde, 257 U.S. 469 (1922). The exception was implicit in the Jensen decision itself. 244 U.S. 205, 216 (1917).

123. 44 Stat. 1424 (1927), as amended, 52 STAT. 1164 (1938), 33 U.S.C. $\&$ 903(a).

124. The courts encounter as much diffculty in excluding "masters and crew members" from the coverage of the Longshoremen's Act as they do in defining "seamen" for purposes of the Jones Act. The decisions are collected in 4 BENEDICT, op. cil. supra note 3, \$§ 635-6.

125. Cases are collected in 4 BENEDICT, op. cit. suppra note $3, \S 612$. See also Hughes, Jurisdictional Conficts Between Admirally and Common Law Cosurls, 6 Tex.B.J. 156 (1943); Morrison, Workmen's Compensation and the Afaritinte Law, 38 YaLE L.J. 472 (1929); 1 Loyola L. Rev. 74 (1941); 7 U. of PrTr. L. Rev. 262 (1941); 10 U. of Car. L. Rev. 339 (1943).

126. It is to be noted, however, that the two year limitation provided in the Longshoremen's Act does not begin to run if a suit is begun under the Jones Act until that suit is adjudicated. 44 Stat. 1424 (1927), as amended, 52 Stat. 1164 (1938), 33 U.S.C. §913(d) (1940).

127. The entire problem is well discussed in 53 YaLE L.J. 348 (1944). 
When the problem was brought directly before the Supreme Court, ${ }^{128}$ its solution was to declare a special "twilight zone," where precedent would be of no assistance, and to hold that a presumption would operate in favor of the jurisdiction of the forum which the suitor had selected. The decision would appear to be of some assistance in protecting the injured worker but it raises another unanswerable question for determination; viz., whether the facts in the situation are sufficiently without precedent to warrant classification of the suit in the "twilight zone" where it would be entitled to the presumptions. ${ }^{129}$

In declaring the "twilight zone" doctrine, the majority of the Court declined to follow Mr. Chief Justice Stone who wished to take the opportunity presented to overrule the Jensen case and with it the derivative "maritime but local" doctrine. ${ }^{130}$ As the situation now exists, moreover, the majority has indicated its view that overruling the Jensen case would be immaterial since the Longshoremen's Act has enacted the "maritime but local" doctrine into statute, and that in interpreting the statute the determination would have to be made anyway. ${ }^{131}$ Congress is disinclined to amend the statute while the Jensen decision is on the books, and the Supreme Court will refuse to consider the constitutional question so long as the problem is presented in terms of statutory construction. ${ }^{132}$ The Jensen doctrine seems thus to be a ghost which none can exorcise; and the Longshoremen's Act must continue to be hobbled by an irrational doctrinal limitation.

\section{The Death on the High Seas Act}

As had been the case with the common law, it is probable that under the general admiralty law there was no right of action for a wrongful death. ${ }^{133}$ Unable to tolerate this archaism, the Supreme Court had permitted suit for maritime deaths under state Wrongful Death statutes prior to the "uniformity" decisions; ${ }^{134}$ and when the problem next arose after the Jensen case, the Court evolved its limitational doctrine of matters "maritime but local" in order to permit the continued application of these statutes. ${ }^{136}$ In line with the philosophy of the "uniformity" rule, the Congress by virtue of its admi-

128. Davis v. Dep't of Labor, 317 U.S. 249 (1942), 53 YALE L.J. 348 (1944), 19 WASII. L. REv. 32 (1944), 67 N.J.L.J. 125, 127, 130 (1944).

129. See discussion in 53 YALE L.J. 348 (1944).

130. Davis v. Dep't of Labor, 317 U.S. 249, 260 (1943). It would seem, however, that the majority tacitly vitiates the "constitutional" support for the Jensen rule by giving effect to the claimant's choice of forum.

131. Parker v. Motor Boat Sales, 314 U.S. 244 (1941).

132. The Supreme Court has displayed a similar reluctance before. See Helvering v. Griffith, 318 U.S. 371 (1943).

133. The Harrisburg, 119 U.S. 199 (1886), was the official determination for American admiralty law that no such right existed. See RoBinson, ADMIRALTY $\$ 16$ (1939).

134. The Hamilton, 207 U.S. 398 (1907). Robinson, Wrongful Death in Admiralty attd the Confitit of Laws, 36 CoL. L. Rev. 406 (1936).

135. See note 122 supra. 
ralty and commerce powers passed the Death on the High Seas Act ${ }^{129}$ a few months before the Jones Act was adopted. The Act grants a right of indemnity to the personal representative, in favor of listed beneficiaries, of any "person" whose death is caused by "wrongful act, neglect or fault" occurring on the high seas beyond a marine league from a possession of the United States. The right is expressly enforceable in rem in the admiralty courts. There has been surprisingly little litigation under the statute and it seems to occupy a relatively minor position among the remedies available to injured maritime workers.

Though the Supreme Court has delivered no opinion on the relationship of the Jones Act and the Death on the High Seas Act, it now seems clear that the Jones Act will be construed as merely offering an alternative remedy to the beneficiaries of a deceased seaman. ${ }^{137}$ The Death on the High Seas Act clearly supersedes state Wrongful Death statutes as they vere formerly applied to deaths on the high seas, but by its terms does not affect such state laws within their own territorial waters. ${ }^{133}$

Although the statute grants jurisdiction in rem to the admiralty courts, it seems that the right may also be enforced in any common law court by virtue of the "saving to suitors" clause. ${ }^{159}$ The statute of limitations under the Act is for but two years while that for the Jones Act is now three; the only defense which is modified by the Death on the High Seas Act is contributory negligence and the beneficiaries are limited. These factors suggest reasons for the apparent preference of personal representatives to prosecute their claims under the Jones Act when applicable.

\section{Conclusions}

Simplicity and symmetry should not be considered the summum bonum to the prejudice of practical considerations of objectives and policies. Neither, on the other hand, should complexity be tolerated where no rational policy is subserved. Multiplicity of remedy where the different strands in the network are closely related entails delay, expense and denial of rights

136. 41 StAT. 537 (1920), 46 U.S.C. $\$ \$ 761-8$ (1940).

137. Van Beeck v. Sabine Towing Co., 300 U.S. 342 (1937). The cases are not clear on the point of damages available. See 1 Benedict, op. cil. supra note $3, \S 144$. Compare Radisich v. Franco-Italian Packing Co., 1946 Am. Mar. Cas. 288 (D. Ct. App. Cal. 1945) (damages limited to pecuniary loss of beneficiaries), willz Pollard v. Seas Shipping Co., 146 F.2d 875 (C.C.A.2d 1945) (damages for pain and suffering allowed); Alice May, 1944 Am. Mar. Cas. 392 (D.Mass. 1943); Libby Maine, 1945 Am. Mar. Cas. 243 (S.D.N.Y. 1943).

138. A related problem not provided for by federal statute has recently been solved through the agency of the "maritime but local" figure. Finding no right under general maritime doctrine to proceed in tort against the estate of a deceased tort feasor, the Supreme Court classified a personal tort in a state's territorial waters as "maritime but local" and sanctioned the application of the state's "survivor" statute. Just v. Chambers, 312 U.S. 383 (1941).

139. Bugden v. Trawler Cambridge, 319 Mass. 315, 65 N.E.2d 533 (1916); Elliott v. Marine Basin Co., 254 App. Div. 739, 4 N.Y.S.2d 9 (2d Dep't 1938). 
through error. There would seem to be little reason in an age of legal realism and reform, why admiralty law should escape the "critic acid" test, or why there should be perpetuated a complex remedial structure developed over a long period of time in adaptation to a series of historical accidents and disfavored doctrines. Brash cutting of the tangled strands by such radical measures as a merger of law and admiralty is not suggested, but some modification of the present system for compensating maritime workers for personal injuries would seem to be in order.

There is little doubt that Congress, by virtue of modern views of its commerce and admiralty powers, could enact a new Longshoremen's Act applicable to all stevedores and covering all injuries on land or navigable waters. It is possible that a genuinely workable solution for the entire problem could be found in some sort of a workmen's compensation scheme for seamen, granting to them, in accord with the traditional policy of special privilege for mariners, higher indemnities and a modified form of the usual "arising out of" formula. Certainly Congress can amend the Jones Act so as to dissolve the jurisdictional cloud which now surrounds it. The rigid barriers between the common-law and the admiralty sides of the federal courts could be relaxed at least sufficiently to permit a "hybrid" suit, thereby expediting litigation through joinders of causes of action with different jurisdictional requirements and lessening the hardships and delays of dismissal. The Supreme Court could overrule the muchly disputed Jensen case and its unnatural progeny, the "maritime but local" doctrine. It could also declare officially dead the moribund fiction that longshoremen are "seamen" and clarify the "exclusive" status of the Jones Act remedy as extended to injuries ashore. The nebulous verbalistic distinctions (and lack thereof) between employer liability based on "negligence" and that predicated on "unseaworthiness" present an urgent need for judicial clarification.

Until these or similar steps are taken, essential rights and remedies will continue to revolve upon a nuance of fact, a twist of interpretation, a random phrase in the pleadings, or a happenstance of conflicting doctrines. There would seem to be little evidence of an abatement in the strong tide moving toward a guarantee of compensation to the injured worker. But so long as no rational overall plan is adopted to effectuate this policy, the sporadic developments of contiguous admiralty remedies will further tangle this elaborate web woven piecemeal to provide for one of the simplest of legal remedies-indemnity for personal injury. ${ }^{140}$

140. See Appendix, infra, pp. 273-4, for a graphic representation of the "Tangled Seine." 
APPENDIX I

\section{Remedies Avallable to "Seamen" and "Masters and Crew Mesibers"}

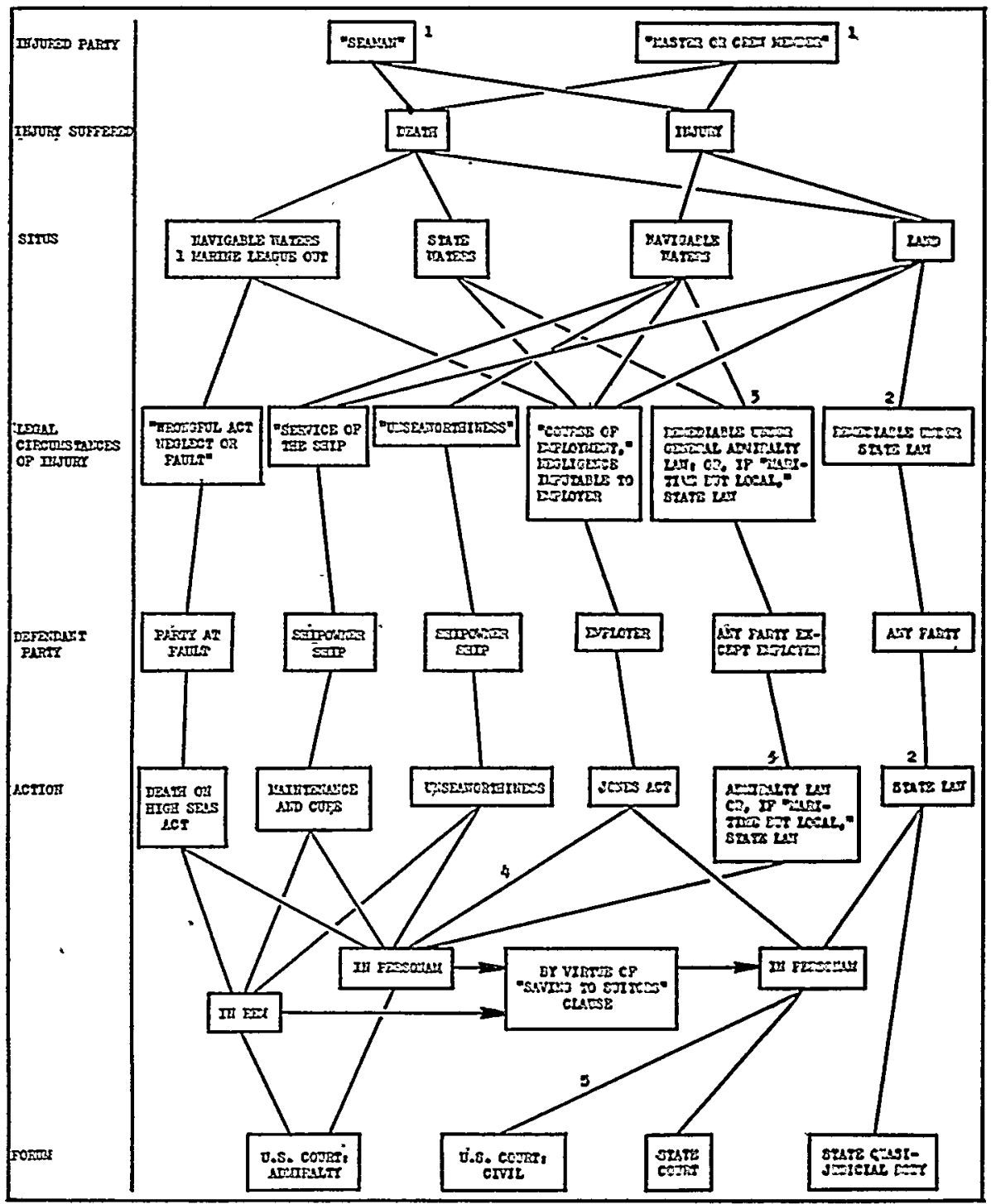

1. The traditional maritime remedies and the Jones Act are limited to "seamen". The Longshoremen's Act however, excludes "masters and crew members." The terms are here treated as synonymous, though the courts will not invariably consider them so.

2. The availability of the state remedy against the employer where the seaman is injured ashore is questionable since the extension of the Jones Act to shore cases.

3. Examples of operable state law are Wrongful Death and Survival statutes.

4. If the Jones Act be recognized as creating a new maritime cause of action (as the better view construes it), the right to a common law trial is granted by the "Saving to Suitors" clause as well as by the specific terms of the Act.

5. Query the jurisdictional requirements for suit on the civil side of the federal court. 


\section{APPENDIX II}

\section{Remedies Available to "Maritime Workers" Other Than "Masters aNd CREW MeMbers"}

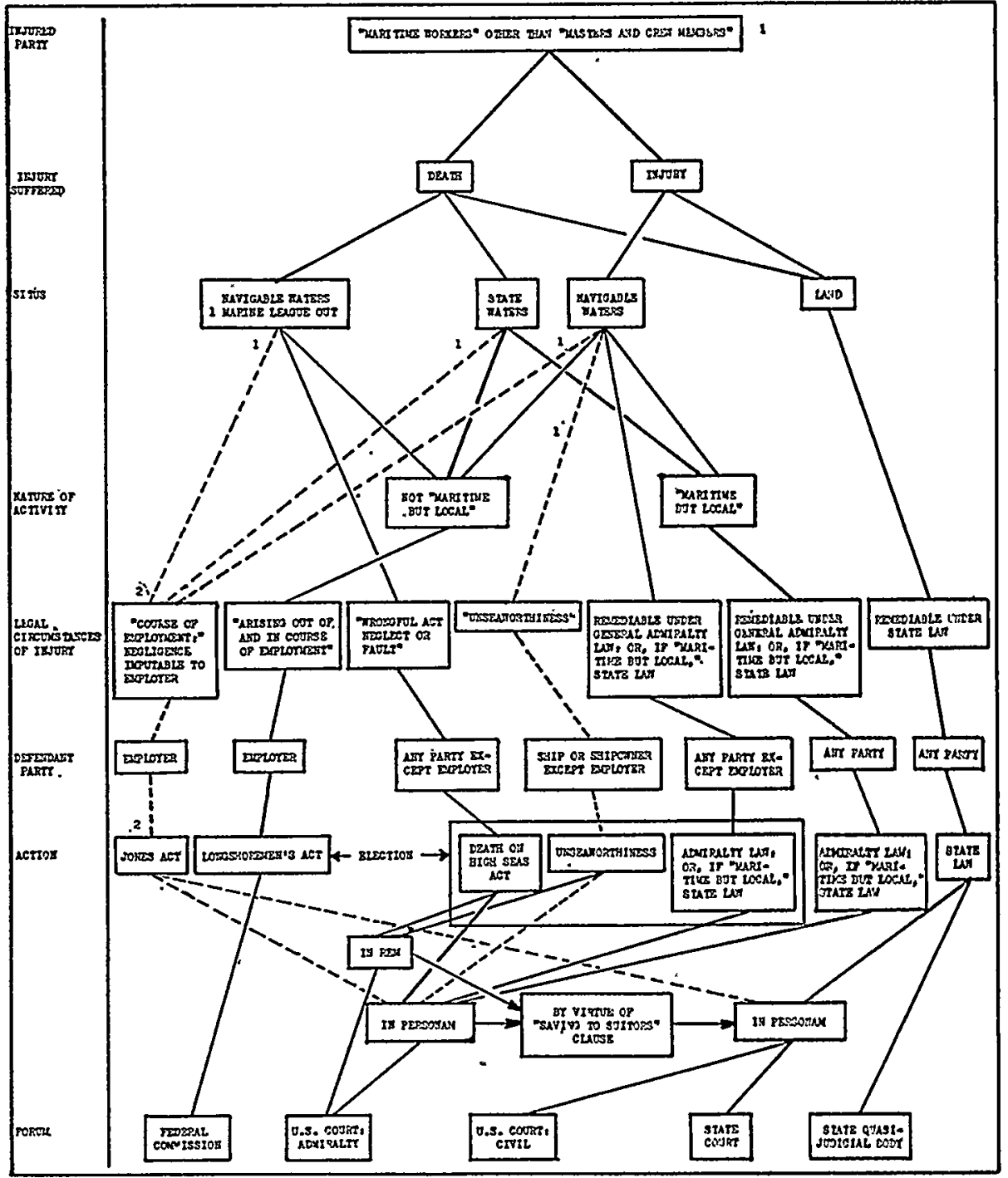

1. The dotted lines represent remedies available so far only to "longshoremen;" but the content of the word is extremely uncertain.

2. The availability of the Jones Act remedy to "longshoremen" is subject to severe qualification, for the "exclusive remedy" provision of the Longshoremen's Act presumably vitiates the doctrine that "longshoremen" are "seamen" under the Jones Act. But a longshoreman injured in an activity "maritime but local" might argue that he may still pursue his Jones Act suit. A similar argument has failed where the longshoreman was injured on land. If the Jones Act were found applicable in such a case, would the overriding federal statute preclude the operation of state law even in the "maritime but local" sphere? 